\title{
Lignin Modification during Eucalyptus globulus Kraft Pulping Followed by Totally Chlorine-Free Bleaching: A Two-Dimensional Nuclear Magnetic Resonance, Fourier Transform Infrared, and Pyrolysis-Gas Chromatography/Mass Spectrometry Study
}

\author{
David Ibarra, ${ }^{\dagger}$ María Isabel Chávez,,$+\neq$ Jorge Rencoret, ${ }^{\S}$ \\ José Carlos Del Río, ${ }^{\S}$ Ana Gutiérrez, ${ }^{\S}$ Javier Romero," \\ Susana Camarero,${ }^{\dagger}$ María Jesús Martínez,${ }^{\dagger}$ Jesús JimÉnez-Barbero, ${ }^{\dagger}$ AND \\ ANGel T. MartínEZ*, \\ Centro de Investigaciones Biológicas, CSIC, Ramiro de Maeztu 9, E-28040 Madrid, Spain, Instituto de \\ Química, UNAM, Ciudad Universitaria, Coyoacán, CP 04510, México, DF, Instituto de Recursos \\ Naturales y Agrobiología, CSIC, P.O. Box 1052, E-41080 Seville, Spain, and CIT, ENCE, Ctra. \\ Campañó, Ribeiro Vao, E-36157 Pontevedra, Spain
}

\begin{abstract}
Chemical modification of eucalypt lignin was investigated during kraft pulping and chlorine-free bleaching by comparing milled wood lignin, kraft lignin, and pulp enzymatic residual lignins. The syringyl-to-guaiacyl ratio $(\mathrm{S} / \mathrm{G})$ from analytical pyrolysis slightly changed during pulping and bleaching $(S / G, 3-4)$ but was higher in the kraft lignin. Semiquantitative heteronuclear single quantum correlation (HSQC) nuclear magnetic resonance (NMR) showed that the relative amount of $\beta-O-4^{\prime}$ (around $80 \%$ side chains) and resinol type substructures (15\%) was slightly modified during pulping and oxygen delignification. However, a decrease of resinol substructures (to only $6 \%$ ) was found after alkaline peroxide bleaching. The relative amount of surviving linkages in the highly phenolic kraft lignin was dramatically modified; resinols were predominant. Oxygen delignification did not change interunit linkages, but a relative increase of oxidized units was found in the HSQC aromatic region, in agreement with the small increase of pyrolysis markers with oxidized side chains. NMR heteronuclear multiple bond correlations showed that the oxidized units after oxygen delignification bore conjugated ketone groups.
\end{abstract}

KEYWORDS: Lignin structure; 2D NMR; HSQC; HMBC; HSQC-TOCSY; analytical pyrolysis; infrared spectroscopy; Eucalyptus globulus; kraft pulping; totally chlorine free bleaching; paper pulp residual lignin

\section{INTRODUCTION}

The use of eucalypt wood for paper pulp manufacture has greatly increased during the last decades. World production has attained 10 million tons/year, that is, near one-third of the total hardwood pulp produced. The increasing use of eucalypt wood includes the production of kraft pulps bleached in totally chlorine free (TCF) sequences, using oxygen and hydrogen peroxide. These high-quality eucalypt pulps are typically used in the manufacture of tissue paper due to their high smoothness and water retention properties. However, studies on eucalypt wood

* To whom correspondence should be addressed. Tel: 34918373112 Fax: 34 915360432. E-mail: ATMartinez@cib.csic.es.

Centro de Investigaciones Biológicas, CSIC.

$\doteqdot$ Instituto de Química, UNAM.

§Instituto de Recursos Naturales y Agrobiología, CSIC.

" CIT, ENCE. lignin and its chemical modification in paper pulp manufacturing are still scarce $(1-4)$. More information on lignins in different eucalypt species and their behavior during pulping and bleaching is needed to optimize the use of this fast-growing forest crop in paper pulp manufacture, including the development of more efficient and environmentally sound industrial technologies.

Milled wood lignin (MWL) (5) is the reference material in many wood lignin studies, in spite of its relatively low yield and the existence of some chemical modifications during milling (6). However, a consensus method for isolating residual lignin from paper pulp does not exist nowadays. Acidolysis is widely used for obtaining lignin from pulp (7), but degradation of alkyl-aryl ether linkages (and an increase of the lignin phenolic content) is inherent to this procedure (8). Enzymatic isolation using cellulolytic enzymes that hydrolyze pulp cellulose, enabling the recovery of lignin, represents an attractive 
alternative due to its mild nature (9), and the combination of modified acidolysis and enzymatic isolation has also been proposed (10). In contrast with acidolysis, which yields pure lignin, the enzymatic lignins are contaminated with cellulases, and purification is required. Moreover, the cellulose hydrolysis conditions and lignin purification methods need to be optimized for each type of pulp. Some studies on Eucalyptus globulus pulp lignin isolated by acidolysis have been reported $(3,4)$, and cellulase charge has been investigated to reduce the contamination of lignin from unbleached Eucalyptus grandis pulp (11). However, only recently, a method for the enzymatic isolation of residual lignin in TCF bleaching of E. globulus pulp has been reported, including a combination of protease hydrolysis and solvent extractions resulting in high-purity unaltered residual lignin with a moderate yield $(12,13)$.

Both degradative and spectroscopic methods have been used to investigate wood lignin structure (14). The analysis of chemical degradation products provides information on lignin composition in terms of its $p$-hydroxyphenyl $(\mathrm{H})$, guaiacyl $(\mathrm{G})$, and syringyl $(\mathrm{S})$ phenylpropanoid units derived from the three $p$-hydroxycinnamyl alcohol precursors (15). Thermal degradation using pyrolysis-gas chromatography/mass spectrometry (Py-GC/MS) has also been used in these studies, including eucalypt wood and pulp lignins $(16,17)$. Information on wood lignin $\mathrm{S} / \mathrm{G}$ ratio and functional groups can also be obtained by infrared spectroscopy (18).

Radical coupling in lignin biosynthesis results in a variety of interunit linkages, often involving the propanoid side chain, conferring high complexity to this polymer (15). From early studies, nuclear magnetic resonance (NMR) spectroscopy emerged as a promising technique to investigate lignin (19). However, the variety of substructures results in overlapping of ${ }^{1} \mathrm{H}$ NMR or ${ }^{13} \mathrm{C}$ NMR signals. Development of two-dimensional (2D) NMR (based on homonuclear and heteronuclear correlations) provided a powerful tool for lignin analysis, since signal overlapping is often resolved (20). Signals corresponding to the main interunit linkages were already identified in the first 2D NMR spectra of lignins $(21,22)$. The recent discovery of dibenzodioxocin (23) and spirodienone (24) substructures constitutes two examples of the potential of this technique for lignin analysis. Two-dimensional NMR has been successfully applied to wood, pulp, and technical lignins, and multidimensional NMR has been developed, enabling additional resolving of overlapping signals $(25-30)$. In addition to the contribution of identifying already known, or even new, structures in lignins, multidimensional NMR can also be used for semiquantitative analysis $(31,32)$.

In the present study, enzymatic residual lignins from $E$. globulus pulp bleached in an industrial type TCF sequence, MWL, and kraft lignin were analyzed by 2D NMR spectroscopy, Fourier transform infrared (FTIR) spectroscopy, and Py-GC/ MS, to identify those structural modifications produced in the course of the pulping and bleaching processes.

\section{MATERIALS AND METHODS}

Eucalypt Kraft Pulping. Wood from 12 to 14 year old E. globulus trees was obtained from ENCE plantations in Pontevedra (Spain). Kraft pulping of industrial chips was performed in a Lorentzen \& Wettre digester at $165{ }^{\circ} \mathrm{C}(50 \mathrm{~min})$, with 3.5 liquor/wood ratio, $25 \%$ sulfidity, and $16 \%$ active alkali. The kraft pulps obtained were disintegrated, washed, and filtered.

TCF Bleaching. Pulp bleaching was performed in $4 \mathrm{~L}$ pressurized reactors at $10 \%$ consistency. An industrial type $\mathrm{O}-\mathrm{O}-\mathrm{Q}-\mathrm{PoP}$ sequence was applied including (i) two oxygen stages (O) using $6 \mathrm{~kg} / \mathrm{cm}^{2} \mathrm{O}_{2}$, $1.5 \% \mathrm{NaOH}$, and $0.5 \% \mathrm{MgSO}_{4}$ for $60 \mathrm{~min}$ at $98{ }^{\circ} \mathrm{C}$; (ii) a chelation stage (Q) using $0.3 \%$ diethylenetriamine penta-acetic acid for $60 \mathrm{~min}$ at $85{ }^{\circ} \mathrm{C}(\mathrm{pH} 5-6)$; and (iii) an alkaline peroxide stage (PoP) using $3 \% \mathrm{H}_{2} \mathrm{O}_{2}, 2 \% \mathrm{NaOH}, 0.1 \% \mathrm{MgSO}_{4}$, and $0.5 \% \mathrm{Na}_{2} \mathrm{Si}_{2} \mathrm{O}_{3}$ for $140 \mathrm{~min}$ at $105{ }^{\circ} \mathrm{C}$ under $6 \mathrm{~kg} / \mathrm{cm}^{2} \mathrm{O}_{2}$, followed by $180 \mathrm{~min}$ at $98{ }^{\circ} \mathrm{C}$ without pressure. The above percentages referred to the pulp dry weight. The pulps were washed after each stage.

Pulp Analyses. Pulp brightness, $\kappa$ number, and intrinsic viscosity were evaluated by standard methods (ISO 3688:1999, ISO 302:1981, and ISO 5351/1:1981, respectively) (33). Hexenuronic acids were estimated spectrophotometrically, and a factor of 0.086 was used to calculate their contribution to the $\kappa$ number. Pulp analyses included up to four replicates.

Isolation of Lignins. MWL was extracted from finely milled wood, free of extractives and hot water soluble material, using dioxane-water (9:1), precipitated, and purified as described (5). Kraft lignin was recovered from the pulping liquor by acid precipitation $(\mathrm{pH} 2.5)$. Residual lignins were enzymatically isolated from unbleached, oxygendelignified $(\mathrm{O}-\mathrm{O})$, and alkaline peroxide-bleached $(\mathrm{O}-\mathrm{O}-\mathrm{Q}-\mathrm{PoP})$ kraft pulps. Fifty grams of pulp (dry weight) at $5 \%$ consistency was hydrolyzed with cellulase and $\beta$-glucosidase $\left(48 \mathrm{~h}\right.$ at $50{ }^{\circ} \mathrm{C}$ ), and lignins, from both hydrolysate and residue, were purified with protease, followed by extractions with dimethylacetamide and $0.5 \mathrm{M} \mathrm{NaOH}$ as previously described (12). Underivatized and acetylated lignins, after $48 \mathrm{~h}$ of treatment in acetic anhydride-pyridine (1:2) for hydroxyl estimation, were analyzed as described below.

NMR Spectroscopy. NMR spectra were recorded at $25{ }^{\circ} \mathrm{C}$ in a Bruker AVANCE $500 \mathrm{MHz}$ equipped with a $z$-gradient triple resonance probe. Forty milligrams of lignin was dissolved in $0.75 \mathrm{~mL}$ of dimethylsulfoxide (DMSO)- $d_{6}$, and ${ }^{1} \mathrm{H}$ NMR and 2D NMR spectra, including HSQC (heteronuclear single quantum correlation), HSQCTOCSY (total correlation spectroscopy), and HMBC (heteronuclear multiple bond correlation) experiments, were recorded. The relaxation delay for the one-dimensional (1D) ${ }^{1} \mathrm{H}$ spectrum was $7 \mathrm{~s}\left(90^{\circ}\right.$ pulse angle). The number of collected points was $32 \mathrm{k}$. The $1 \mathrm{D}$ spectra were processed using an exponential weighting function of $0.2 \mathrm{~Hz}$ for ${ }^{1} \mathrm{H}$ prior to Fourier transform. The spectral widths for the HSQC were 5000 and $13200 \mathrm{~Hz}$ for the ${ }^{1} \mathrm{H}$ and ${ }^{13} \mathrm{C}$ dimensions, respectively. For $\mathrm{HMBC}$, the ${ }^{13} \mathrm{C}$ dimension was increased to $30000 \mathrm{~Hz}$. For both HSQC and HMBC, the number of collected complex points was 2048 for the ${ }^{1} \mathrm{H}$ dimension with a recycle delay of $5 \mathrm{~s}$. The number of transients for the HSQC spectra was 64 (128 for HMBC), and 256 time increments were always recorded in the ${ }^{13} \mathrm{C}$ dimension. The $J$-coupling evolution delay was set to $3.2 \mathrm{~ms}$ in $\mathrm{HSQC}$, while for $\mathrm{HMBC}$, experiments with a $66 \mathrm{~ms}$ long-range $J$-coupling evolution time were recorded. For HSQC experiments, a squared cosine-bell apodization function was applied in both dimensions. Prior to Fourier transform, the data matrixes were zero filled up to 1024 points in the ${ }^{13} \mathrm{C}$ dimension. Residual DMSO (from DMSO- $d_{6}$ ) was used as a reference for chemical shifts. Twodimensional NMR cross-signals were assigned by combining the results of the different experiments and comparing them with the literature $(2,20,25,26,29,34,35)$.

A semiquantitative analysis of the HSQC cross-signal intensities was performed $(25,31)$. Because the cross-signal intensity depended on the particular ${ }^{1} J_{\mathrm{CH}}$ value, as well as on the $\mathrm{T}_{2}$ relaxation time, a direct analysis of the intensities was indeed impossible. Thus, the integration of the cross-signals was performed separately for the different regions of the HSQC spectra, which contain signals that correspond to chemically analogous carbon-proton pairs (in similar samples). For these signals, the ${ }^{1} J_{\mathrm{CH}}$ coupling value was relatively similar and was used semiquantitatively to estimate the relative abundance of the different species.

In the aliphatic oxygenated region, interunit linkages were estimated from $\mathrm{C}_{\alpha}-\mathrm{H}_{\alpha}$ correlations to avoid possible interference from homonuclear ${ }^{1} \mathrm{H}-{ }^{1} \mathrm{H}$ couplings, and the relative abundance of side chains involved in interunit linkages and terminal structures was calculated (with respect to total side chains). In the aromatic region, $\mathrm{C}-\mathrm{H}$ correlations from $S$ and $G$ type units were used to estimate the $S / G$ ratio of lignin, and the percentage of oxidized units. The volume integrals were corrected for proton numbers.

Total hydroxyls were estimated by integrating the acetyl region (1.4$2.8 \mathrm{ppm}$ ) in the ${ }^{1} \mathrm{H}$ NMR spectra of acetylated lignins and referred to 
Table 1. Main Characteristics of Unbleached Kraft Pulp, Oxygen-Delignified (O-O) Pulp, and TCF-Bleached (O-O-Q-PoP) Pulp from E. globulus

\begin{tabular}{|c|c|c|c|}
\hline & \multicolumn{3}{|c|}{ pulp } \\
\hline & kraft & $0-0$ & O-O-Q-PoP \\
\hline$\kappa$ number & 14.2 & 10.5 & 6.7 \\
\hline $\begin{array}{l}\text { hexenuronic acid content } \\
\text { (meguiv } / \mathrm{kg} \text { ) }\end{array}$ & 45.9 & 44.7 & 38.4 \\
\hline brightness (\% ISO) & 41.2 & 55.5 & 87.9 \\
\hline intrinsic viscosity $(\mathrm{mL} / \mathrm{g})$ & 1188 & 997 & 758 \\
\hline
\end{tabular}

aromatic units estimated from integration of the $6.2-7.6 \mathrm{ppm}$ region in the same spectra, taking the $\mathrm{S} / \mathrm{G}$ ratio into account. Separate integration of aliphatic (alcoholic) and aromatic (phenolic) acetates signals (to estimate their relative percentages) was performed both in ${ }^{1} \mathrm{H}$ NMR (1.97 and $2.23 \mathrm{ppm}$, respectively) and HSQC 2D NMR spectra $\left(\delta_{\mathrm{C}} / \delta_{\mathrm{H}} 20.8 / 1.97\right.$ and $20.5 / 2.23 \mathrm{ppm}$, respectively).

Infrared Spectroscopy. FTIR spectra were obtained with a Bruker IF-28 spectrometer using $1 \mathrm{mg}$ of lignin in $300 \mathrm{mg}$ of $\mathrm{KBr}$. A total of 50 interpherograms were accumulated, and the spectra were corrected by baseline subtraction between valleys at 1850 and $900 \mathrm{~cm}^{-1}$.

Analytical Pyrolysis. Lignins $(0.1 \mathrm{mg})$ were introduced in quartz tubes of a CDS Pyroprobe AS-2500 autosampler. Pyrolyses were carried out at $550{ }^{\circ} \mathrm{C}$ for $10 \mathrm{~s}$, and the chamber (at $250{ }^{\circ} \mathrm{C}$ ) was purged with He. The pyrolyzer was connected to an Agilent 6890 gas chromatograph, fitted with an in-column injector and a $60 \mathrm{~mm} \times 0.25 \mathrm{~mm}$ i.d., $0.25 \mu \mathrm{m}, \mathrm{DV}-1701$ fused-silica capillary column (J\&W Scientific, Folsom, CA) coupled to an Agilent 5973N mass spectrometer. The GC oven was heated from $45(4 \mathrm{~min})$ to $280{ }^{\circ} \mathrm{C}$ at $4{ }^{\circ} \mathrm{C} / \mathrm{min}$ and held for $15 \mathrm{~min}$. The injector and transfer line were at 250 and $280{ }^{\circ} \mathrm{C}$, respectively. Py-GC/MS compounds were identified $(16,17)$. Analyses were carried out in quadruplicate.

\section{RESULTS}

The effect of kraft pulping and TCF bleaching on E. globulus lignin was investigated. With this purpose, MWL from wood, kraft lignin from pulping liquor, and residual lignins enzymatically isolated from unbleached, oxygen-delignified, and peroxidebleached kraft pulps were compared. The $\kappa$ number, hexenuronic acid content, brightness, and intrinsic viscosity of these laboratory pulps are shown in Table $\mathbf{1}$. Higher brightness values (over $90 \%$ ISO) are obtained in industrial production, together with slightly lower $\kappa$ numbers and hexenuronic acid contents.

Whole NMR Spectra. The main structural characteristics of the five lignins, including different units linked by ether and $\mathrm{C}-\mathrm{C}$ bonds (Figure 1), were revealed by the HSQC NMR spectra (Figures 2-4) in combination with the HSQC-TOCSY (Figure 5) and HMBC spectra (Figure 6). The main lignin cross-signals assigned in the HSQC spectra of nonacetylated samples are listed in Table 2.

The HSQC spectra (Figure 2) showed three regions corresponding to aliphatic, oxygenated aliphatic, and aromatic ${ }^{13} \mathrm{C}-$ ${ }^{1} \mathrm{H}$ correlations, the two latter being described below. The aliphatic (nonoxygenated) region showed signals of lipids, lignin degradation products, and other unidentified compounds; therefore, it is not discussed in detail. In acetylated lignins, this region also includes a strong signal of acetyl correlations, in both alcoholic $\left(\delta_{\mathrm{C}} / \delta_{\mathrm{H}} 20.8 / 1.97 \mathrm{ppm}\right)$ and phenolic $\left(\delta_{\mathrm{C}} / \delta_{\mathrm{H}} 20.5 / 2.23\right.$ ppm) acetates (Figure 2C and inset). Signals of anomeric $\mathrm{C}_{1}-$ $\mathrm{H}_{1}\left(\delta_{\mathrm{C}} / \delta_{\mathrm{H}} 102.2 / 4.25 \mathrm{ppm}\right)$ correlation are indicated in Figure 2D, whereas other carbohydrate signals are mentioned below. No cross-signals were observed in the $\delta_{\mathrm{C}} 150-205 \mathrm{ppm}$ region (that is not shown in Figure 2). The HSQC spectra also showed (i) five signals $\left(\delta_{\mathrm{C}} / \delta_{\mathrm{H}} 19.8 / 1.04,70.2 / 3.50,72.6 / 3.43,72.8 / 3.33\right.$, and $75 / 3.50 \mathrm{ppm}$ ) assigned to poly(ethyleneoxy-propyleneoxy)
Table 2. Assignment of Main Lignin ${ }^{13} \mathrm{C}-{ }^{1} \mathrm{H}$ Cross-Signals in the HSQC Spectra of Eucalypt MWL, Kraft Lignin, and Pulp Residual Lignins Shown in Figures 2-4 (Nonacetylated Samples)

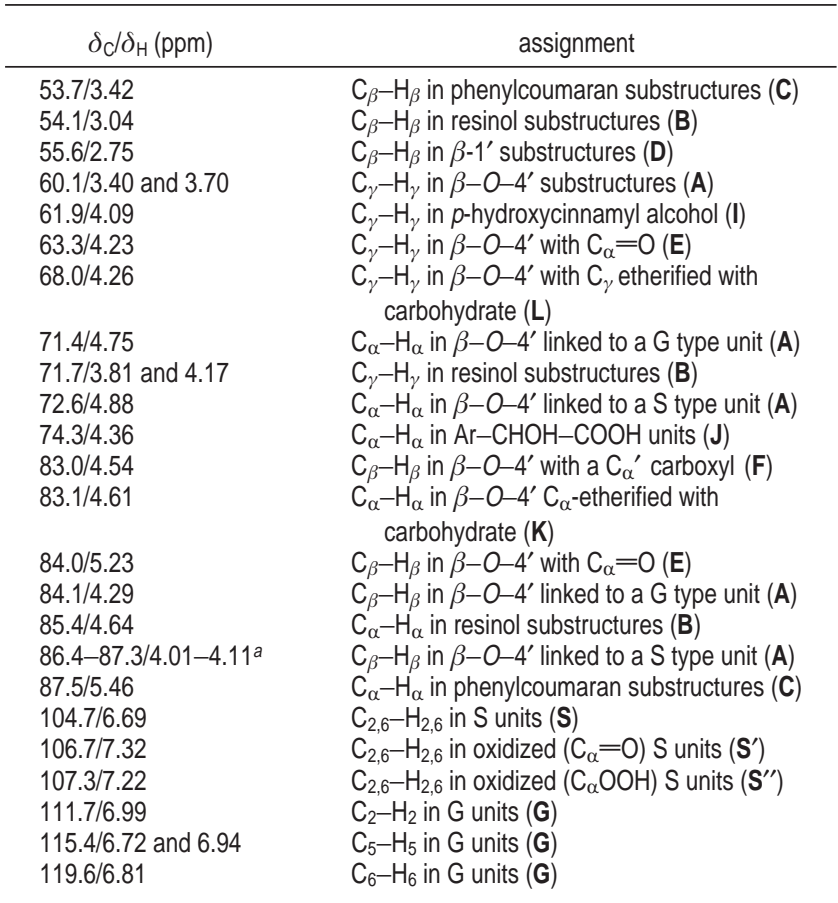

${ }^{a}$ Include $\mathrm{C}_{\beta}-\mathrm{H}_{\beta}$ signals, at $\delta_{C} / \delta_{H} 86.4 / 4.11$ and $87.3 / 4.01 \mathrm{ppm}$, corresponding, respectively, to the erythro and threo forms of side chains $\beta-0-4^{\prime}$-linked to an $S$ unit.

(Figure 2F) and (ii) three signals $\left(\delta_{\mathrm{C}} / \delta_{\mathrm{H}} 21.8 / 1.94,34.9 / 2.78\right.$, and $37.9 / 2.94 \mathrm{ppm}$ ) corresponding to dimethylacetamide used in lignin purification (Figure 2D).

Side-Chain Region in HSQC (and HSQC-TOCSY) NMR Spectra. Expansions of the oxygenated aliphatic region in the HSQC are shown in Figure 3. Cross-signals of methoxyls $\left(\delta_{\mathrm{C}}\right)$ $\delta_{\mathrm{H}} 56.2 / 3.73 \mathrm{ppm}$ ) and side chains in $\beta-O-4^{\prime}$ and resinols substructures were the most prominent, together with some carbohydrate cross-signals.

The main signals corresponded to $\beta-O-4^{\prime}$ (A) $\mathrm{C}_{\alpha}-\mathrm{H}_{\alpha}$ and $\mathrm{C}_{\beta}-\mathrm{H}_{\beta}$ correlations, and resinol (B) $\mathrm{C}_{\alpha}-\mathrm{H}_{\alpha}, \mathrm{C}_{\beta}-\mathrm{H}_{\beta}$, and double $\mathrm{C}_{\gamma}-\mathrm{H}_{\gamma}$ correlations (Figure 3). The resinol and phenylcoumaran $\mathrm{C}_{\beta}-\mathrm{H}_{\beta}$ cross-signals are included together with the oxygenated aliphatic ones because of their proximity. The above assignments, and the two $\beta-O-4^{\prime} \mathrm{C}_{\gamma}-\mathrm{H}_{\gamma}$ cross-signals that in the HSQC spectra overlapped with related signals, were confirmed in HSQC-TOCSY experiments that showed a set of ${ }^{1} \mathrm{H}-{ }^{1} \mathrm{H}$ correlations (Figure 5). $\mathrm{C}_{\beta}-\mathrm{H}_{\beta}$ correlations in $\beta-O-4^{\prime}$ substructures gave different cross-signals if the second unit was an $\mathrm{S}$ or $\mathrm{G}$ unit (Figure 3). Moreover, $\mathrm{C}_{\beta}-\mathrm{H}_{\beta}$ correlations corresponding to the erythro and threo forms of the $\mathrm{S}$ type $\beta-O-4^{\prime}$ substructure could be observed (at $\delta_{\mathrm{C}} / \delta_{\mathrm{H}} 86.4 / 4.11$ and 87.3/4.01 ppm, respectively).

Signals of phenylcoumaran (C) $\mathrm{C}_{\alpha}-\mathrm{H}_{\alpha}, \mathrm{C}_{\beta}-\mathrm{H}_{\beta}$, and $\mathrm{C}_{\gamma}-$ $\mathrm{H}_{\gamma}$ correlations, $\beta$ - $1^{\prime}$ (D) $\mathrm{C}_{\beta}-\mathrm{H}_{\beta}$ correlations, and $\beta-O-4^{\prime}$ with a $\mathrm{C}_{\alpha}$ carbonyl (E) $\mathrm{C}_{\beta}-\mathrm{H}_{\beta}$ and $\mathrm{C}_{\gamma}-\mathrm{H}_{\gamma}$ correlations were also detected (Figure 3), although with much lower intensities than those from normal ( $\mathrm{C}_{\alpha}$-hydroxylated) $\beta-O-4^{\prime}$ and resinol substructures. Cross-signals of lignin terminal structures included (i) $\mathrm{C}_{\beta}-\mathrm{H}_{\beta}$ correlation in a $\beta-O-4^{\prime}$ substructure that was tentatively identified as bearing a carboxyl group in $\mathrm{C}_{\alpha^{\prime}}(\mathbf{F})$, (ii) $p$-hydroxycinnamyl (I) $\mathrm{C}_{\gamma}-\mathrm{H}_{\gamma}$ correlation, and (iii) $\mathrm{C}_{\alpha}-$ $\mathrm{H}_{\alpha}$ correlation in an oxidized unit that was tentatively identified 
<smiles>[Z]c1cc(OC)c(O[C@H](CO)[C@@H](O)c2cc(OC)c(OC(C)(F)F)c(OC)c2)c(OC)c1</smiles><smiles>[CH]Oc1c(OC)cc([C@H]2OC[C@@H]3C(c4cc(OC)c(OC)c(OC)c4)OC[C@H]23)cc1OC</smiles>

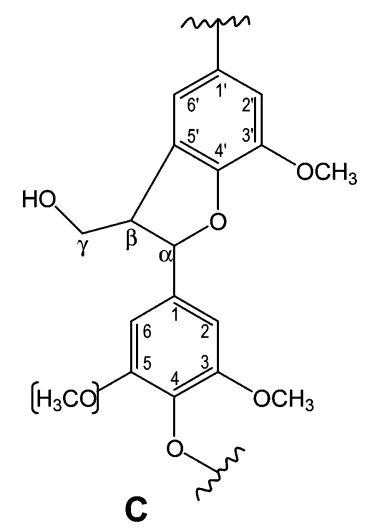<smiles>COc1cc([C@H](O)C(CO)c2cc(OC)c(OC)c(C(C)(C)C)c2)cc(OC)c1OC(C)(C)C</smiles><smiles>COc1cc(C(=O)C(CO)Oc2c(OC)cc(C)cc2OC)cc(OC)c1OCC(C)(F)F</smiles><smiles>COc1cc(C(=O)O)cc(OC)c1OC(CO)C(O)c1cc(OC)c(OC(F)(F)F)c(OC)c1</smiles><smiles>CCOc1ccc(C(C)O)cc1OC</smiles>

G<smiles>CCOc1c(OC)cc(/C=C/CO)cc1OC</smiles>

I<smiles>COc1cc(C(O)C(=O)O)cc(OC)c1OC</smiles>

J<smiles>[R]OC[C@H](Oc1c(OC)cc([Z])cc1OC)C(O[R])c1cc(OC)c(OC(C)C)c(OC)c1</smiles>

$K, L$

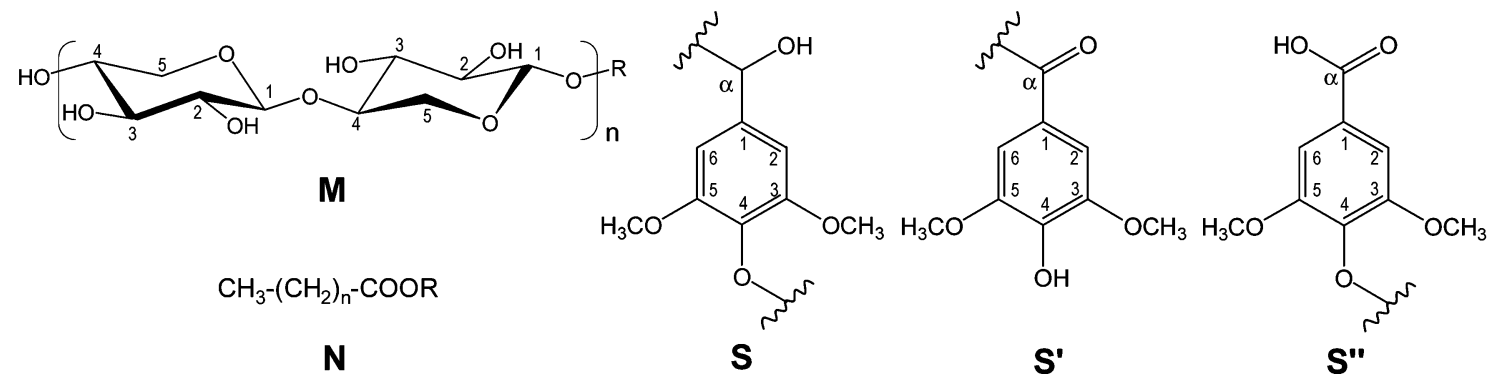

Figure 1. Main structures identified in eucalypt lignin: $\mathbf{A}, \beta-0-4^{\prime} ; \mathbf{B}$, resinols with $\beta-\beta^{\prime}, \alpha-O-\gamma^{\prime}$, and $\gamma-0-\alpha^{\prime}$ linkages; $\mathbf{C}$, phenylcoumaran with $\alpha-0-4^{\prime}$ and $\beta-0-5^{\prime}$ linkages; $\mathbf{D}, \beta-1^{\prime} ; \mathbf{E}, \mathrm{C}_{\alpha}$-oxidized $\beta-0-4^{\prime} ; \mathbf{F}$, terminal $\beta-0-4^{\prime}$ with a $\mathrm{C}_{\alpha}{ }^{\prime}$ carboxyl; $\mathbf{G}$, guaiacyl unit; I, $p$-hydroxycinnamyl alcohol terminal unit; J, terminal unit with $\mathrm{C}_{\beta}$ carboxyl; $\mathrm{K}, \beta-\mathrm{O}-4^{\prime}$ substructure $\mathrm{C}_{\alpha}$ ether-linked to carbohydrate $\left(\mathrm{R}\right.$, carbohydrate; $\left.\mathrm{R}^{\prime}, \mathrm{H}\right) ; \mathrm{L}, \beta-\mathrm{O}-4^{\prime}$ substructure $\mathrm{C}_{\gamma}$ ether-linked to carbohydrate (R, H; $R^{\prime}$, carbohydrate); $\mathbf{M}$, xylan (R, carbohydrate linked to lignin, e.g., in $\mathbf{K}$ or $\left.L\right) ; \mathbf{N}$, free $(R, H)$ or esterified fatty acids; S, S unit; $\mathbf{S}^{\prime}$, oxidized $\mathbf{S}$ unit with a $\mathrm{C}_{\alpha}$ ketone (phenolic); and $\mathbf{S}^{\prime \prime}$, oxidized $\mathrm{S}$ unit with a carboxyl in $\mathrm{C}_{\alpha}$ (only those side-chain structures with an HSQC relative abundance $>1 \%$ are shown).

as bearing a carboxyl group in $\mathrm{C}_{\beta}(\mathbf{J})$. Carbohydrate-related signals included (i) $\mathrm{C}_{\alpha}-\mathrm{H}_{\alpha}$ and $\mathrm{C}_{\gamma}-\mathrm{H}_{\gamma}$ correlations in $\beta-O-$ $4^{\prime}$ substructures that are $\mathbf{C}_{\alpha}$-etherified $(\mathbf{K})$ and $\mathbf{C}_{\gamma}$-etherified ( $\left.\mathbf{L}\right)$ with carbohydrate and (ii) $\mathrm{C}_{2}-\mathrm{H}_{2}\left(\delta_{\mathrm{C}} / \delta_{\mathrm{H}} 73.5 / 3.01 \mathrm{ppm}\right), \mathrm{C}_{3}-$
$\mathrm{H}_{3}\left(\delta_{\mathrm{C}} / \delta_{\mathrm{H}} 75.3 / 3.32 \mathrm{ppm}\right), \mathrm{C}_{4}-\mathrm{H}_{4}\left(\delta_{\mathrm{C}} / \delta_{\mathrm{H}} 75.3 / 3.49 \mathrm{ppm}\right)$, and $\mathrm{C}_{5}-\mathrm{H}_{5}\left(\delta_{\mathrm{C}} / \delta_{\mathrm{H}} 63.4 / 3.20\right.$ and $\left.3.67 \mathrm{ppm}\right)$ correlations in xylan chains (M), whose $\mathrm{C}_{1}-\mathrm{H}_{1}$ cross-signal is indicated in Figure 2D, together with a set of unidentified cross-signals in the $\delta_{\mathrm{C}}$ l 

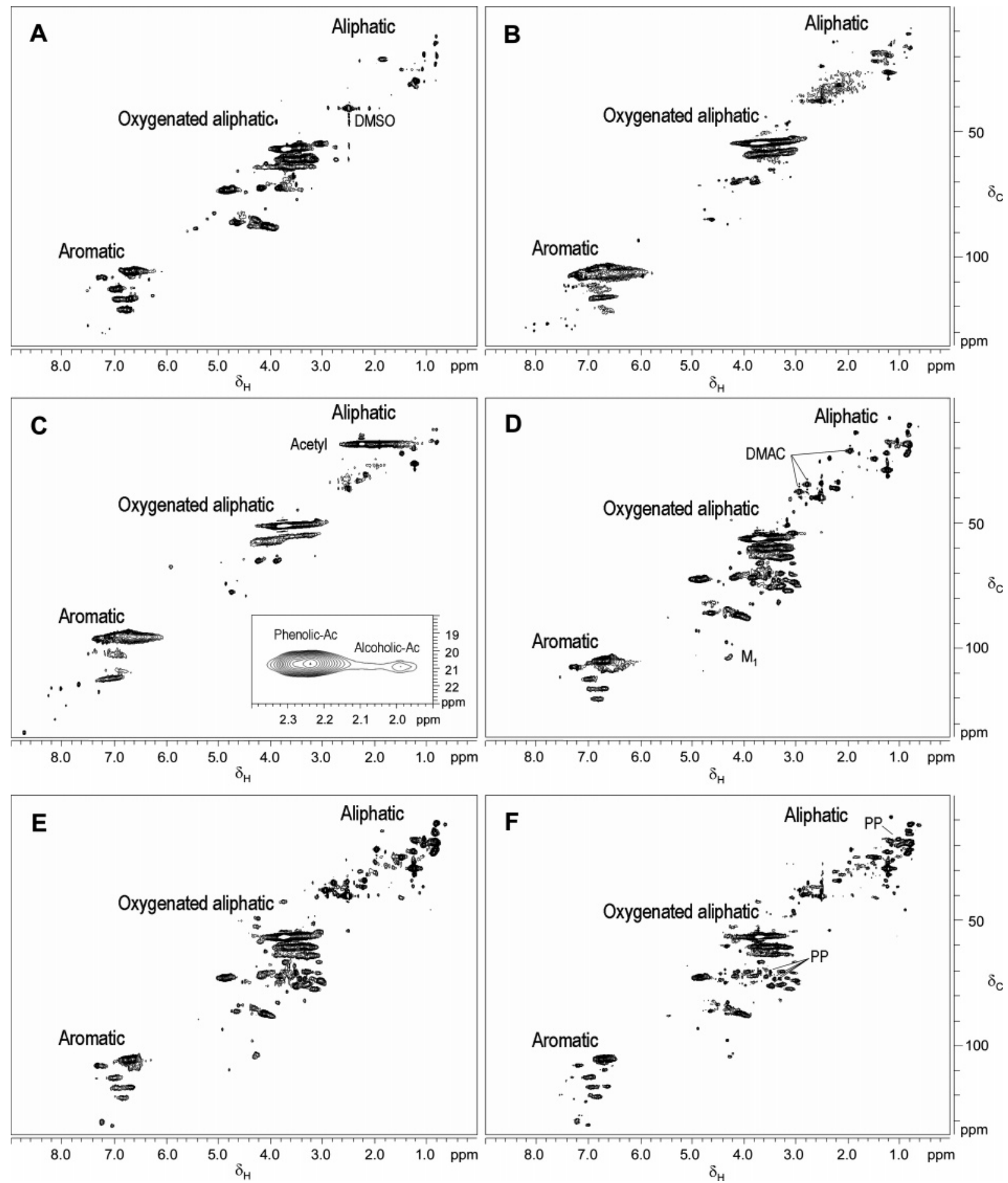

Figure 2. Total HSQC 2D NMR spectra, $\delta_{\mathrm{C}} / \delta_{\mathrm{H}}$ 0-135/0-9 ppm: (A) MWL, (B) kraft lignin, (C) acetylated kraft lignin, (D) residual lignin from unbleached eucalypt kraft pulp, (E) residual lignin from oxygen-delignified kraft pulp, and (F) residual lignin from TCF-bleached kraft pulp. The aliphatic, oxygenated aliphatic, and aromatic regions are observed. Cross-signals of the residual DMSO, anomeric carbon of xylan $\left(\mathrm{M}_{1}\right)$, and contaminating dimethylacetamide (DMAC) and poly(ethyleneoxy-propyleneoxy) (PP) are indicated in $\mathbf{A}, \mathbf{D}$, and $\mathbf{F}$ (and also present in other samples). The inset in $\mathbf{C}$ shows a detail of the acetyl region $\left(\delta_{C} / \delta_{H} 18-23 / 1.9-2.4 \mathrm{ppm}\right)$ at lower intensity, enabling identification of the alcoholic and phenolic acetate cross-signals.

$\delta_{\mathrm{H}} 67-75 / 3.0-3.8 \mathrm{ppm}$ region that could correspond to hexose units in carbohydrates.

Aromatic Region in HSQC (and HSQC-TOCSY) NMR Spectra. Expansions of the unsaturated region of the HSQC spectra are shown in Figure 4. The main cross-signals corresponded to the aromatic rings of lignin units. In $\mathrm{S}$ units, only $\mathrm{C}_{2}$ and $\mathrm{C}_{6}$ are protonated resulting in a unique and large signal. By contrast, different cross-signals were assigned to $\mathrm{G}$ units $\mathrm{C}_{2}-\mathrm{H}_{2}, \mathrm{C}_{5}-\mathrm{H}_{5}$, and $\mathrm{C}_{6}-\mathrm{H}_{6}$ correlations.
Some minor signals $\left(\delta_{\mathrm{C}} / \delta_{\mathrm{H}} 125.7 / 7.79\right.$ and 8.05 and $128.8 /$ $7.24 \mathrm{ppm}$ ) could correspond to olefinic correlations in stilbene type structures, but their assignment was not confirmed. Low intensity (and broad) cross-signals with $\delta_{\mathrm{C}} / \delta_{\mathrm{H}} 109.5 / 6.94$ and $110.9 / 6.65 \mathrm{ppm}$ could correspond, respectively, to $\mathrm{C}_{2}-\mathrm{H}_{2}$ and $\mathrm{C}_{6}-\mathrm{H}_{6}$ correlations in unit $\mathrm{A}$ of $5-\mathrm{O}-4^{\prime}$ structures, but they were not definitively assigned. The two cross-signals with $\delta_{\mathrm{C}} /$ $\delta_{\mathrm{H}} 115.4 / 6.63$ and $130.5 / 7.03 \mathrm{ppm}$, the former overlapping with $\mathrm{C}_{5}-\mathrm{H}_{5}$ in $\mathrm{G}$ units, corresponded to $\mathrm{C}_{2,6}-\mathrm{H}_{2,6}$ and $\mathrm{C}_{3,4}-\mathrm{H}_{3,4}$ 

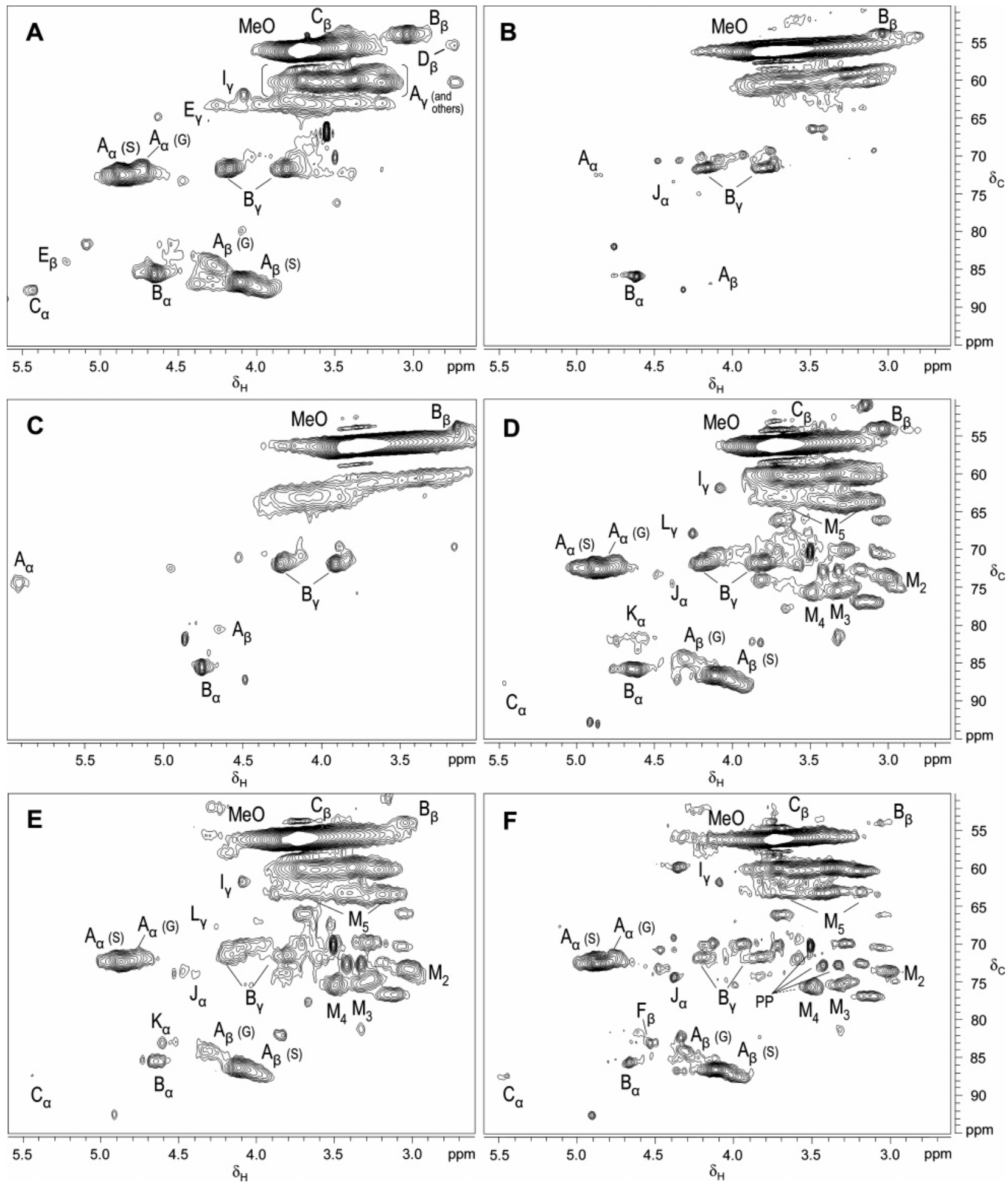

Figure 3. Expanded side-chain region of the HSQC spectra: (A) MWL, (B) kraft lignin, (C) acetylated kraft lignin, (D) residual lignin from unbleached eucalypt kraft pulp, (E) residual lignin from oxygen-delignified kraft pulp, and (F) residual lignin from TCF-bleached kraft pulp $\left(\delta_{\mathrm{C}} / \delta_{\mathrm{H}} 50-95 / 2.6-5.6 \mathrm{ppm}\right.$; except $\delta_{\mathrm{C}} / \delta_{\mathrm{H}}$ 50-95/3-6 ppm in C). Figure 1 shows the different structures identified. Cross-signals of methoxyls (MeO) are also shown. Four crosssignals assigned to contaminating poly(ethyleneoxy-propyleneoxy) (PP), one of them overlapping with M4, are indicated in $\mathbf{F}$ (and also present in $\mathbf{D}$ and $\mathbf{E})$.

correlations in lignin $\mathrm{H}$ units or protein tyrosine residues, as confirmed by their crossed correlation $\left(\delta_{\mathrm{C}} / \delta_{\mathrm{H}} 130.5 / 6.63 \mathrm{ppm}\right)$ in the HSQC-TOCSY spectrum (Figure 5A).

Signals assigned to $\mathrm{C}_{2,6}-\mathrm{H}_{2,6}$ correlation in $\mathrm{C}_{\alpha}$-oxidized $\mathrm{S}$ units $\left(\mathbf{S}^{\prime}\right.$ and $\mathbf{S}^{\prime \prime}$ ) were found in the HSQC spectra. Two small signals with $\delta_{\mathrm{C}} / \delta_{\mathrm{H}} 111 / 7.5$ and $124 / 7.5 \mathrm{ppm}$ could correspond to similar $\mathrm{C}_{2}-\mathrm{H}_{2}$ and $\mathrm{C}_{6}-\mathrm{H}_{6}$ correlations in $\mathrm{G}$ units, but their assignment was not confirmed. The nature of the above oxidized units was revealed by the HMBC experiments.

HMBC NMR Spectra. The HMBC spectra of MWL and residual lignin from oxygen-delignified and TCF-bleached pulps are shown (Figure 6), and a list of the most significant lignin cross-signals is shown in Table 3. The whole spectra (Figure 6A,D,G, respectively) showed different signals, including 


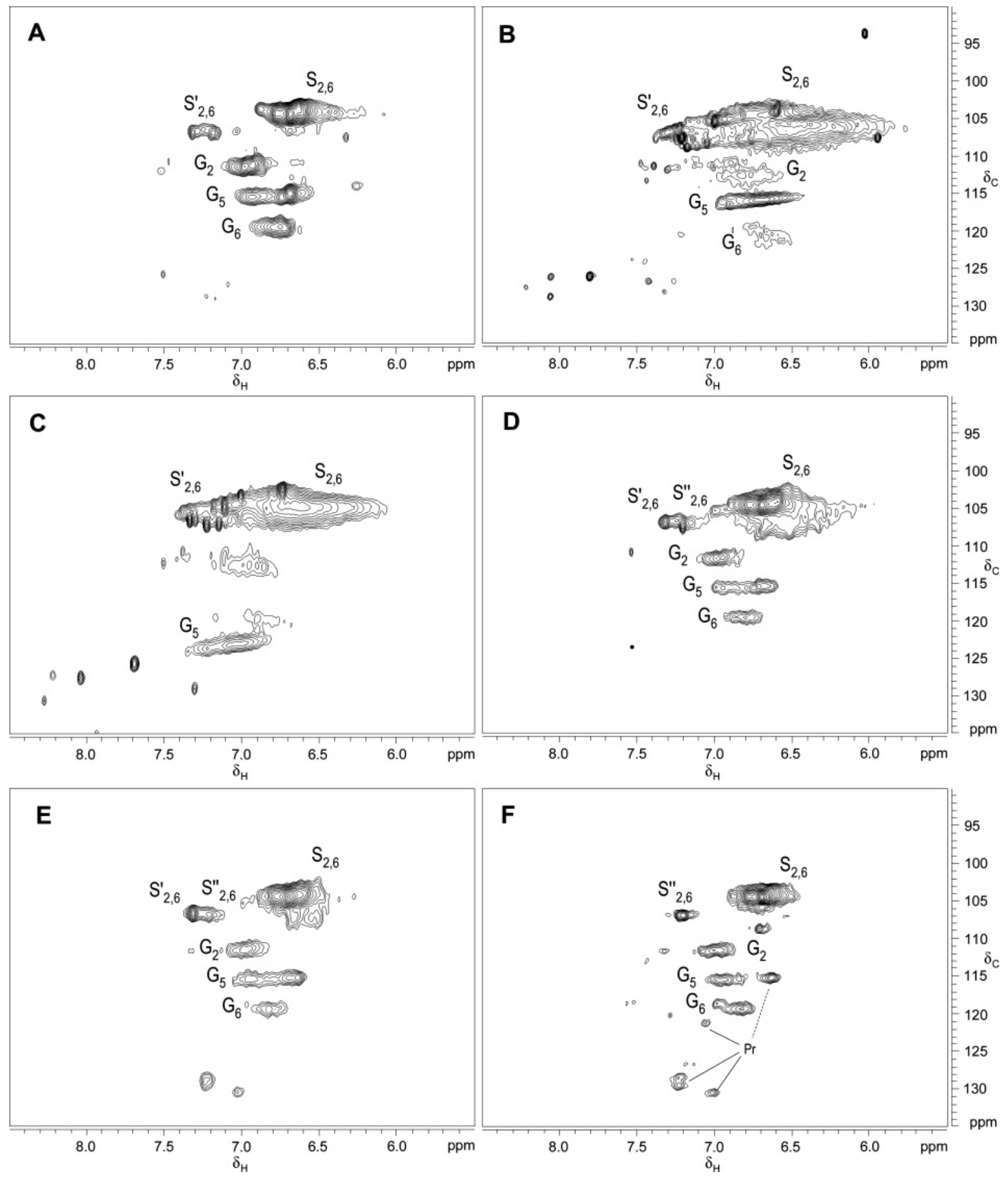

Figure 4. Expanded aromatic region of the HSQC spectra, $\delta_{\mathrm{C}} / \delta_{\mathrm{H}} 90-135 / 5.5-8.5 \mathrm{ppm}$ : (A) MWL, (B) kraft lignin, (C) acetylated kraft lignin, (D) residual lignin from unbleached eucalypt kraft pulp, (E) residual lignin from oxygen-delignified kraft pulp, and (F) residual lignin from TCF-bleached kraft pulp. Figure 1 shows the different structures identified. Cross-signals for contaminant protein ( $\mathrm{Pr}$ ) are indicated in $\mathbf{F}$ (and are also present in $\mathbf{E}$ ).

correlations between alkyl protons (at $1.8-2.2 \mathrm{ppm}$ ) and carboxyl carbons (at $170-175 \mathrm{ppm}$ ) assigned to free/esterified fatty acids $(\mathbf{N})$. However, the most interesting information was found in the expanded $\delta_{\mathrm{H}} 6-8 \mathrm{ppm}$ region (Figure 6B,E,H). This region showed the correlations between $\mathrm{H}_{2,6}$ in normal (6.69 ppm) and oxidized (7.22-7.32 ppm) $\mathrm{S}$ units (whose HSQC cross-signals are shown in Figure $\mathbf{6 C , F}, \mathbf{I})$ and $\mathrm{C}_{1}, \mathrm{C}_{2,6}$, $\mathrm{C}_{3,5}$, and $\mathrm{C}_{4}$ situated at 1-2 C-bond distance. Moreover, correlations with hydroxylated $\mathrm{C}_{\alpha}$ (in $\beta-O-4^{\prime}$ substructures), $\mathrm{C}_{\alpha}=\mathrm{O}$, and $\mathrm{C}_{\alpha} \mathrm{OOH}$ were found in the $\mathrm{HMBC}$ spectra of MWL and residual lignins from oxygen-delignified and TCF-bleached pulps, respectively (S, $\mathbf{S}^{\prime}$, and $\mathbf{S}^{\prime \prime}$ structures).

Some of the above $\mathrm{H}_{2,6}$ correlations indicated that the $\mathrm{C}_{\alpha}=$ $\mathrm{O} S$ units were basically phenolic $\left(\mathrm{C}_{3,5}\right.$ correlation at $\left.148 \mathrm{ppm}\right)$, whereas the normal and $\mathrm{C}_{\alpha} \mathrm{OOH} \mathrm{S}$ units were etherified $\left(\mathrm{C}_{3,5}\right.$ correlation at $152 \mathrm{ppm}) . \mathrm{C}_{3,5}$ in etherified and phenolic $\mathrm{S}$ units also correlated with the protons of their methoxy substituents with $\delta_{\mathrm{C}} / \delta_{\mathrm{H}} 152 / 3.7$ and $148 / 3.8 \mathrm{ppm}$, respectively, although the latter cross-signal also included $\mathrm{C}_{3}-\mathrm{H}_{\mathrm{MeO}}$ correlations in minor $\mathrm{G}$ units. Signals of aromatic quaternary carbons were also found 

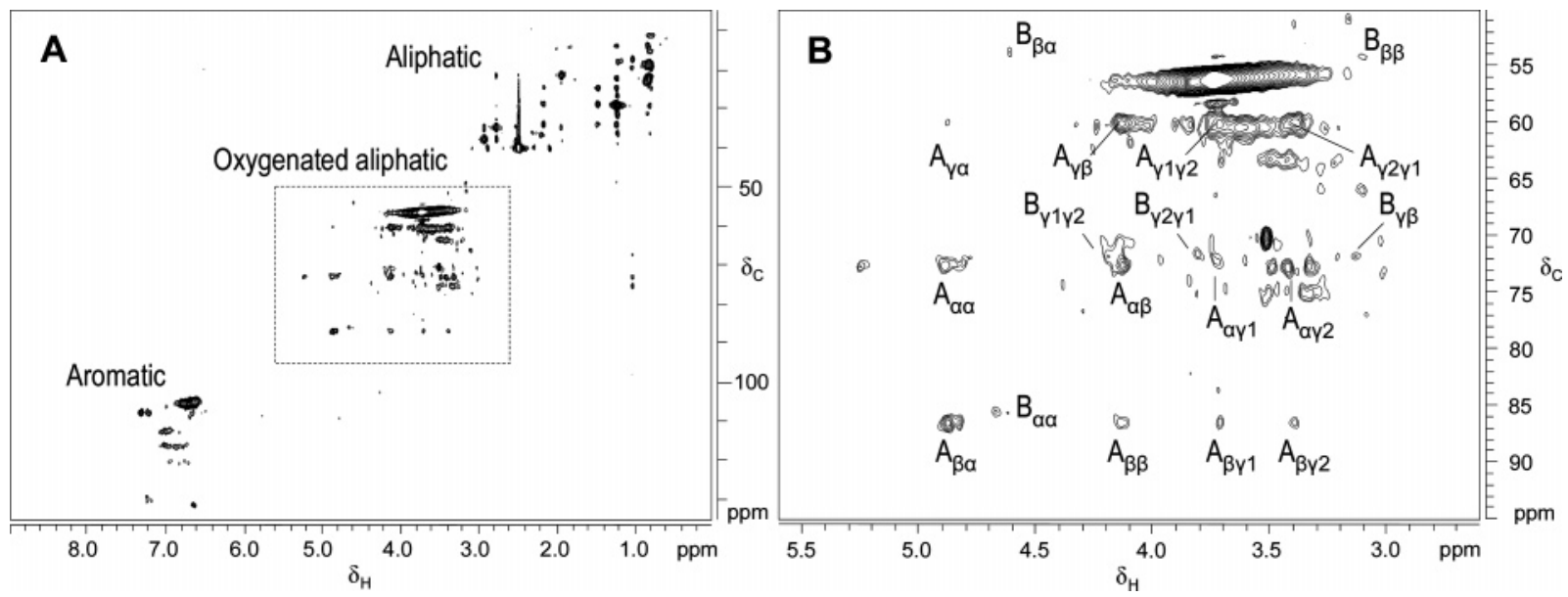

Figure 5. HSQC-TOCSY of residual lignin from oxygen-delignified eucalypt kraft pulp: $(\mathbf{A})$ total spectrum, $\delta_{\mathrm{C}} / \delta_{\mathrm{H}} 0-135 / 0-9 \mathrm{ppm}$, and (B) expanded oxygenated aliphatic region, $\delta_{\mathrm{C}} / \delta_{\mathrm{H}} 50-95 / 2.6-5.6 \mathrm{ppm}$, showing ${ }^{1} \mathrm{H}-{ }^{1} \mathrm{H}$ correlations of $\mathrm{H}_{\alpha}\left(\alpha \alpha, \alpha \beta\right.$, $\alpha \gamma_{1}$, and $\left.\alpha \gamma_{2}\right), \mathrm{H}_{\beta}\left(\beta \alpha, \beta \beta, \beta \gamma_{1}\right.$, and $\left.\beta \gamma_{2}\right)$, and $\mathrm{H}_{\gamma}\left(\gamma \alpha, \gamma \beta, \gamma_{1} \gamma_{2}\right.$, and $\left.\gamma_{2} \gamma_{1}\right)$ that confirmed the identification of the side-chain cross-signals (a rectangle in $\mathbf{A}$ indicates the region expanded in $\left.\mathbf{B}\right)$.

in ${ }^{13} \mathrm{C}$ NMR spectra (not shown) with $\delta_{\mathrm{C}} 152\left(\mathrm{C}_{3,5}\right.$ in etherified $\mathrm{S}$ units $)$ and $148 \mathrm{ppm}\left(\mathrm{C}_{3,5}\right.$ in phenolic $\mathrm{S}$ units, together with $\mathrm{C}_{3,4}$ in $\mathrm{G}$ units).

NMR Spectra of Acetylated Lignins. The same side-chain cross-signals described for underivatized lignins were observed in the HSQC spectra of acetylated lignins, although their position was affected (Figure 3C). The main $\delta_{\mathrm{C}}$ difference corresponded to $\mathrm{C}_{\beta}-\mathrm{H}_{\beta}$ correlation in $\beta-O-4^{\prime}$ substructures $\left(\delta_{\mathrm{C}} / \delta_{\mathrm{H}} 80.5 /\right.$ $4.65 \mathrm{ppm}$ ), and the main $\delta_{\mathrm{H}}$ difference was that of $\mathrm{C}_{\alpha}-\mathrm{H}_{\alpha}$ correlation in the same substructures $\left(\delta_{\mathrm{C}} / \delta_{\mathrm{H}} 74.5 / 5.91 \mathrm{ppm}\right)$, whereas the resinol cross-signals were affected in a minor extent $\left(\mathrm{C}_{\alpha}-\mathrm{H}_{\alpha}, \mathrm{C}_{\beta}-\mathrm{H}_{\beta}\right.$, and $\mathrm{C}_{\gamma}-\mathrm{H}_{\gamma}$ correlations with $\delta_{\mathrm{C}} / \delta_{\mathrm{H}} 85.4 / 4.67$, $54.1 / 3.13$, and $71.7 / 3.9$ and $4.23 \mathrm{ppm}$, respectively) since no free hydroxyls are present in the side chains of these substructures. Acetylation also caused a strong change of the aromatic $\mathrm{C}_{5}-\mathrm{H}_{5}$ correlation $\left(\delta_{\mathrm{C}} / \delta_{\mathrm{H}} 123.0 / 7.02 \mathrm{ppm}\right)$ in $\mathrm{G}$ units (Figure 4C). However, no modifications were observed in the HSQC cross-signals of $\mathrm{S}$ units since the two protonated carbons are meta to $\mathrm{C}_{4}$ where phenol acetylation is taking place.

The amount of hydroxyls per lignin unit, estimated from ${ }^{1} \mathrm{H}$ NMR spectra (not shown), varied from 1.7 in kraft lignin to 3.6 in oxygen-delignified lignin, with values around 2 hydroxyls/ unit in the other lignin samples. The phenolic and alcoholic acetate signals were better separately integrated in the HSQC spectra (Figure 2C, inset) resulting in percentages of phenolic hydroxyls that varied from $8 \%$ in the oxygen-delignified pulp lignin to $83 \%$ in kraft lignin. From these values, a percentage of phenolic units around 25-35\% was estimated for MWL and pulp lignins, whereas kraft lignin showed around one hydroxyl group per aromatic ring, as average.

FTIR Spectra. All of the infrared spectra showed typical lignin patterns including the triplet at 1504-1422 and the 1594$1609 \mathrm{~cm}^{-1}$ band due to aromatic ring vibrations. The FTIR spectra showed a higher intensity of bands assigned to (i) aromatic ring breathing in $\mathrm{S}$ units $\left(1326-1330 \mathrm{~cm}^{-1}\right.$ band) than in $\mathrm{G}$ units (1263-1270 $\mathrm{cm}^{-1}$ shoulder), (ii) aromatic in-plane bending in $\mathrm{S}$ units $\left(1114-1126 \mathrm{~cm}^{-1}\right)$ than in $\mathrm{G}$ units $(1032-$ $1033 \mathrm{~cm}^{-1}$ ), and (iii) out-of-plane $\mathrm{C}-\mathrm{H}$ bending in $\mathrm{S}$ units $\left(833-836 \mathrm{~cm}^{-1}\right)$ than in $\mathrm{G}$ units $\left(913-916 \mathrm{~cm}^{-1}\right)$. Bands around 1660 and at $1714-1725 \mathrm{~cm}^{-1}$ were assigned to stretching of carbonyls conjugated and unconjugated with the aromatic ring, respectively, although the former can also be due to amide carbonyl stretching, and the second one to carboxyl groups. Bands of aliphatic $\left(1740 \mathrm{~cm}^{-1}\right)$ and phenolic acetates (1770 $\mathrm{cm}^{-1}$ ) were found in the spectra of acetylated lignins. The band around $1510 \mathrm{~cm}^{-1}$ decreased with acetylation suggesting that it includes phenolic units.

Analytical Pyrolysis. Two representative pyrograms are shown in Figure 7. Assignment and molar relative abundances of the main peaks, all of them derived from lignin, are included in Table 4. They corresponded to guaiacol (peak 1) and syringol (peak 4) and their methyl (peaks 2 and 6), ethyl (peak 10), vinyl (peaks 3 and 12), propenyl (peaks 5, 15, and 17), propine (peaks 8 and 16), and allyl derivatives (peak 14). Syringol and 4-vinylsyringol were the major products from most samples. Aromatic ( $\mathrm{G}$ and $\mathrm{S}$ type) aldehydes (peaks 7, 9, 18, and 19), ketones (peaks 11, 13, 21, 23, and 24), and methyl esters (peak 20) were also identified, as well as cinnamic type aldehydes (peaks 22 and 26) and alcohols (peak 25). Table 4 also shows the molar $\mathrm{S} / \mathrm{G}$ ratios and percentages of oxidized $\left(\mathrm{C}_{6}-\mathrm{C}=\mathrm{O}\right)$ and shortened $\left(\mathrm{C}_{6}-\mathrm{C}_{0-1}\right)$ side chain $\mathrm{Py}-\mathrm{GC} / \mathrm{MS}$ products.

Some $\mathrm{H}$ type compounds, such as phenol and 4-methylphenol, were detected in kraft (around $0.2 \%$ of total) and residual lignins (around $0.5 \%$ in lignins from oxygen-delignified and TCF pulps and lower amounts in unbleached kraft pulp lignin) being nearly absent from MWL ( $0.1 \%$ of total). These compounds in the residual lignin pyrograms were accompanied by similar amounts of indole and 3-methylindole from protein tryptophan residues (see Figure 7B).

\section{DISCUSSION}

Eucalypt Wood Lignin. The first structural models for spruce, pine, or beech lignins were established near 40 years ago (8); however, eucalypt lignin has been investigated in much lesser detail despite the increasing use of this wood as a raw material in paper manufacturing.

The E. globulus wood lignin was characterized by a high abundance of $\mathrm{S}$ units and a near complete absence of $\mathrm{H}$ units. The molar S/G ratio from Py-GC/MS (and HSQC NMR) of $E$. globulus MWL was estimated to be around 3. Its FTIR spectrum only showed a $1270 \mathrm{~cm}^{-1}$ shoulder as compared with the intense band at $1330 \mathrm{~cm}^{-1}$. The high $\mathrm{S} / \mathrm{G}$ ratio of lignin in E. globulus wood has been related to its easier pulping (16). Its phenolic content was in the same order of MWL from other hardwoods (36) and a little higher than reported previously for E. globulus (3).

A characteristic of the E. globulus lignin is the high predominance of $\beta-O-4^{\prime}$ interunit linkages, whose abundance 

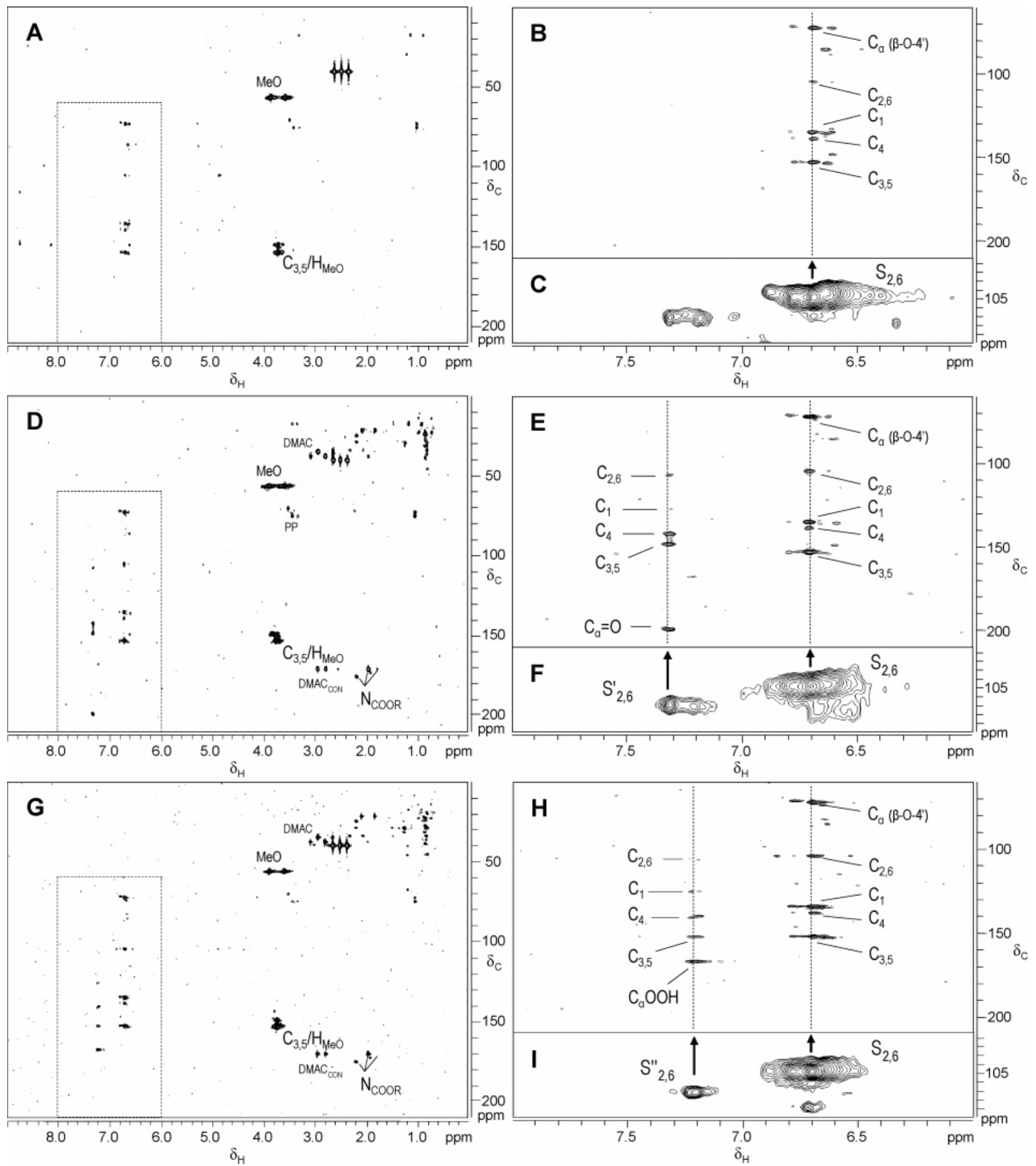

Figure 6. Total HMBC spectra (left) and expanded $\delta_{H} 6-8$ ppm region of HMBC (right, top) and HSQC (right, bottom) spectra: (A-C) MWL, (D-F) residual lignin from oxygen-delignified eucalypt kraft pulp, and (G-I) residual lignin from TCF-bleached kraft pulp (rectangles indicate the regions expanded). $\mathrm{C}_{2,6}-\mathrm{H}_{2,6}$ cross-signals corresponding to oxidized $\left(\delta_{C} / \delta_{H} 107 / 7.3 \mathrm{ppm}\right)$ and nonoxidized $\mathrm{S}$ units $\left(\delta_{C} / \delta_{H} 105 / 6.7 \mathrm{ppm}\right)$ are shown in the HSQC spectra (C $\mathbf{F}$, and I). The expanded HMBC spectra revealed different multiple-bond ${ }^{13} \mathrm{C}-{ }^{1} \mathrm{H}$ correlations between $\mathrm{H}_{2,6}$ and different carbons in the oxidized and nonoxidized units (lines in $\mathbf{B}, \mathbf{E}$, and $\mathbf{H}$ ). Cross-signals of methoxyls, lipids, and contaminating dimethylacetamide, including proton to amide carbon correlation $\left(\mathrm{DMAC}_{\mathrm{CoN}}\right)$, and poly(ethyleneoxy-propyleneoxy) (PP) are also shown in the whole HMBC spectra.

in MWL was estimated as 79\% of side chains (including 2\% of $\mathrm{C}_{\alpha}=\mathrm{O}$ substructures), followed by resinol (16\%) and small percentages of phenylcoumaran (2\%) and $\beta-1^{\prime}$ linkages (2\%), together with a low percentage $(1 \%)$ of $p$-hydroxycinnamyl alcohol terminal structures. As mentioned by Heikkinen et al. (31), the cross-signal intensity in HSQC experiments is related to $\sin ^{2}\left(\pi \Delta /{ }^{1} J_{\mathrm{CH}}\right)$, where $\Delta$ is the time for evolution of the heteronuclear coupling constants. Therefore, because the above semiquantitative analysis was focused on similar carbon-proton pairs in analogous samples, which should also have both similar
T2 relaxation times and ${ }^{1} J_{\mathrm{CH}}$ values (32), the maximum error in integrations could be less than $10 \%$. For a detailed discussion on quantitative HSQC NMR of polymers, see Zhang and Gellerstedt (32).

An erythrolthreo ratio of 8.3 was calculated for the $\mathrm{S}$ type $\beta-O-4^{\prime}$ substructures in agreement with the tendency of S units to favor the erythro isomer (37). In contrast, a near 1:1 ratio has been reported in softwood lignin (25). Taking into account the high S/G ratio of E. globulus lignin, syringaresinol will be the main resinol type substructure (together with some pinores- 
Table 3. Assignment of Lignin ${ }^{13} \mathrm{C}-{ }^{1} \mathrm{H}$ Cross-Signals Involving Quaternary Carbons in the HMBC Spectra of Eucalypt MWL and Pulp Residual Lignins Shown in Figure 6

\begin{tabular}{cl}
\hline$\delta_{\mathrm{C}} / \delta_{\mathrm{H}}(\mathrm{ppm})$ & \multicolumn{1}{c}{ assignment } \\
\hline $127.1 / 7.19$ & $\mathrm{C}_{1}-\mathrm{H}_{2,6}$ in oxidized $\left(\mathrm{C}_{\alpha} \mathrm{OOH}\right) \mathrm{S}$ units $\left(\mathbf{S}^{\prime \prime}\right)$ \\
$127.1 / 7.32$ & $\mathrm{C}_{1}-\mathrm{H}_{2,6}$ in oxidized $\left(\mathrm{C}_{\alpha}=\mathrm{O}\right) \mathrm{S}$ units $\left(\mathbf{S}^{\prime}\right)$ \\
$134.7 / 6.69$ & $\mathrm{C}_{1}-\mathrm{H}_{2,6}$ in $\mathrm{S}$ units $(\mathbf{S})$ \\
$138.4 / 6.69$ & $\mathrm{C}_{4}-\mathrm{H}_{2,6}$ in $\mathrm{S}$ units $(\mathbf{S})$ \\
$140.7 / 7.19$ & $\mathrm{C}_{4}-\mathrm{H}_{2,6}$ in oxidized $\left(\mathrm{C}_{\alpha} \mathrm{OOH}\right) \mathrm{S}$ units $\left(\mathbf{S}^{\prime \prime}\right)$ \\
$141.5 / 7.32$ & $\mathrm{C}_{4}-\mathrm{H}_{2,6}$ in oxidized $\left(\mathrm{C}_{\alpha}=\mathrm{O}\right) \mathrm{S}$ units $\left(\mathbf{S}^{\prime}\right)$ \\
$148.0 / 7.32$ & $\mathrm{C}_{3,5}-\mathrm{H}_{2,6}$ in oxidized $\left(\mathrm{C}_{\alpha}=\mathrm{O}\right) \mathrm{S}$ units (phenolic) $\left(\mathbf{S}^{\prime}\right)$ \\
$152.5 / 6.69$ & $\mathrm{C}_{3,5}-\mathrm{H}_{2,6}$ in etherified $\mathrm{S}$ units $(\mathbf{S})$ \\
$152.5 / 7.19$ & $\mathrm{C}_{3,5}-\mathrm{H}_{2,6}$ in oxidized $\left(\mathrm{C}_{\alpha} \mathrm{OOH}\right) \mathrm{S}$ units (etherified) $\left(\mathbf{S}^{\prime \prime}\right)$ \\
$167.3 / 7.19$ & $\mathrm{C}_{\text {carboxyy }}-\mathrm{H}_{2,6}$ in oxidized $\left(\mathrm{C}_{\alpha} \mathrm{OOH}\right) \mathrm{S}$ units $\left(\mathbf{S}^{\prime \prime}\right)$ \\
$197.9 / 7.32$ & $\mathrm{C}_{\text {carbonyl }}-\mathrm{H}_{2,6}$ in oxidized $\left(\mathrm{C}_{\alpha}=0\right)$ S units $\left(\mathbf{S}^{\prime}\right)$ \\
\hline
\end{tabular}
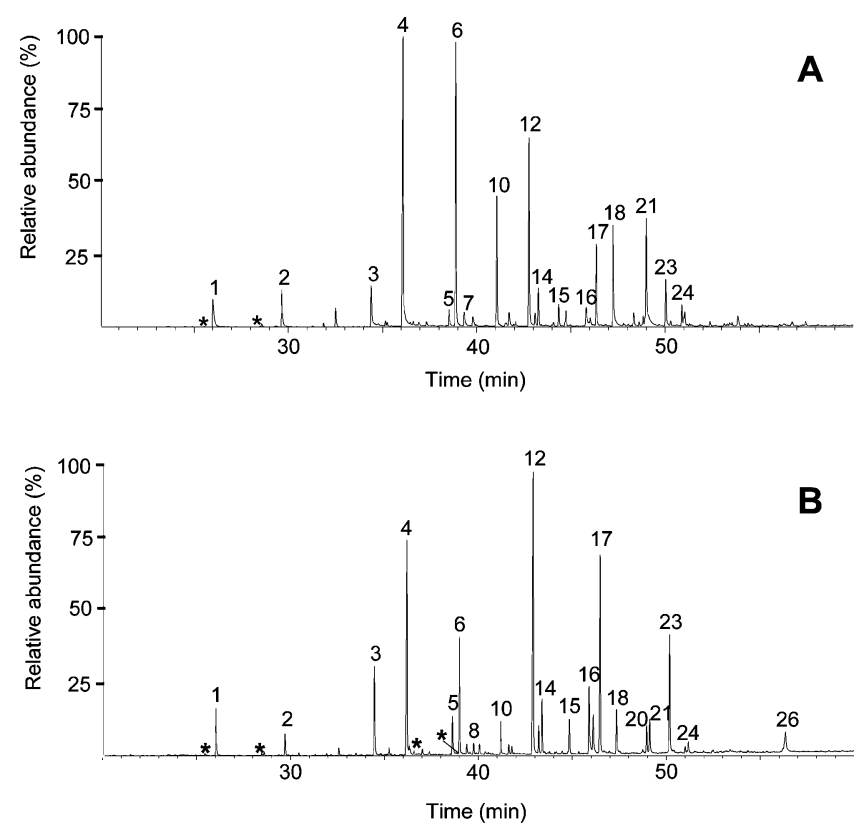

Figure 7. Py-GC/MS, 20-60 min chromatograms: (A) kraft lignin and (B) residual lignin from TCF-bleached kraft pulp. See Table 4 for identification of the main Py-GC/MS peaks. Minor peaks corresponding to phenol, 4-methylphenol, indole, and 3-methyl indole (left to right) are indicated with asterisks.

inol and mixed $\mathrm{S}-\mathrm{G}$ structure). In the same sense, the $p$-hydroxycinnamyl alcohol terminal structures probably corresponded to $\mathrm{C}_{4}$-etherified sinapyl alcohol. The absence of $\mathrm{C}_{\alpha}-$ $\mathrm{H}_{\alpha}$ and $\mathrm{C}_{\beta}-\mathrm{H}_{\beta}$ cross-signals has been explained by the lower sensitivity of 2D NMR olefinic signals (26). Coniferyl alcohol has been reported in softwood MWL based on the $\mathrm{C}_{\gamma}-\mathrm{H}_{\gamma}$ correlation signal (25). Spirodienones, described in lignin (24), have been detected in MWL from five eucalypt species (unpublished), with $\mathrm{C}_{\alpha}-\mathrm{H}_{\alpha}, \mathrm{C}_{\beta}-\mathrm{H}_{\beta}, \mathrm{C}_{2}-\mathrm{H}_{2}$, and $\mathrm{C}_{6}-\mathrm{H}_{6}$ crosssignals at $\delta_{\mathrm{C}} / \delta_{\mathrm{H}} 81.8 / 5.08,60.4 / 2.73,107.4 / 6.33$, and 114.4/ $6.25 \mathrm{ppm}$, respectively, but their abundance was low in $E$. globulus.

The above results differ from those recently reported for $E$. grandis MWL (2) that included a S/G ratio of 1.7 and only 3\% of units bond by resinol type linkages. However, a higher resinol content (13\% units) has been reported for E. globulus dioxane lignin, although with a higher $\mathrm{S} / \mathrm{G}$ ratio of 6 (1). A small percentage of $\mathrm{H}$ units has been reported in eucalypt lignin (1, 2); however, we failed to confirm it in E. globulus MWL, where the amount of $\mathrm{H}$ units from Py-GC/MS was around $0.1 \%$.

Modifications of Eucalypt Lignin during Pulping. Kraft pulping is the most common wood pulping method, and the
Table 4. Py-GC/MS of Eucalypt MWL, Kraft Lignin, and Residual Lignins from Kraft, Oxygen-Delignified (O-O), and TCF-Bleached (O-O-Q-PoP) Pulps (S/G Ratios and Percentages of Oxidized and Short Side-Chain Products Are Also Shown) ${ }^{a}$

\begin{tabular}{|c|c|c|c|c|c|}
\hline & MWL & $\begin{array}{l}\text { kraft } \\
\text { lignin }\end{array}$ & $\begin{array}{l}\text { kraft pulp } \\
\text { lignin }\end{array}$ & $\begin{array}{l}0-0 \\
\text { lignin }\end{array}$ & $\begin{array}{c}\mathrm{O}-\mathrm{O}-\mathrm{Q}-\mathrm{PoP} \\
\text { lignin }\end{array}$ \\
\hline 1. guaiacol & 3.7 & 3.9 & 6.1 & 6.5 & 3.8 \\
\hline 2. 4-methylguaiacol & 2.4 & 3.7 & 1.7 & 1.8 & 1.5 \\
\hline 3. 4-vinylguaiacol & 7.7 & 3.4 & 6.2 & 6.3 & 5.9 \\
\hline 4. syringol & 12.2 & 23.7 & 18.4 & 19.3 & 13.8 \\
\hline 5. $t$-isoeugenol & 1.9 & 1.1 & 3.3 & 3.2 & 2.5 \\
\hline 6. 4-methylsyringol & 7.2 & 16.7 & 4.8 & 4.9 & 6.0 \\
\hline 7. vanillin & 1.0 & 1.4 & 1.0 & 1.4 & 0.8 \\
\hline 8. 4-propineguaiacol & 1.7 & 0.0 & 1.1 & 0.5 & 1.0 \\
\hline 9. homovanillin & 1.3 & 0.0 & 0.2 & 0.1 & 0.0 \\
\hline 10. 4-ethylsyringol & 2.5 & 6.5 & 1.4 & 1.9 & 1.3 \\
\hline 11. acetoguaiacone & 1.0 & 1.0 & 0.8 & 0.9 & 0.5 \\
\hline 12. 4-vinylsyringol & 18.0 & 10.5 & 14.5 & 14.2 & 18.4 \\
\hline 13. guaiacylacetone & 0.8 & 0.7 & 1.5 & 1.8 & 1.4 \\
\hline 14. 4-allylsyringol & 1.5 & 1.9 & 2.2 & 2.4 & 2.6 \\
\hline 15. c-4-propenylsyringol & 1.0 & 1.0 & 1.3 & 1.6 & 1.5 \\
\hline 16. 4-propinesyringol & 5.5 & 1.9 & 7.7 & 3.2 & 8.5 \\
\hline 17. $t$-4-propenylsyringol & 7.4 & 4.0 & 8.8 & 9.7 & 10.2 \\
\hline 18. syringaldehyde & 3.7 & 6.8 & 3.0 & 3.4 & 2.8 \\
\hline 19. homosyringaldehyde & 2.8 & 0.8 & 0.1 & 0.1 & 0.0 \\
\hline 20. methyl syringate & 0.2 & 0.4 & 0.5 & 0.8 & 1.3 \\
\hline 21. acetosyringone & 3.7 & 5.7 & 2.6 & 2.6 & 2.1 \\
\hline 22. $t$-coniferaldeyde & 1.0 & 0.0 & 0.0 & 0.0 & 0.0 \\
\hline 23. syringylacetone & 3.0 & 2.3 & 5.1 & 6.6 & 6.3 \\
\hline 24. propiosyringone & 0.7 & 0.9 & 0.5 & 0.5 & 0.3 \\
\hline 25. $t$-sinapyl alcohol & 1.3 & 0.0 & 0.0 & 0.0 & 0.0 \\
\hline 26. $t$-sinapaldehyde & 5.3 & 0.0 & 3.4 & 2.7 & 4.0 \\
\hline S/G ratio & 3.2 & 5.2 & 3.0 & 3.0 & 3.9 \\
\hline $\mathrm{C}_{6}-\mathrm{C}=\mathrm{O}(\%)^{b}$ & 18.6 & 20.6 & 16.4 & 19.4 & 16.8 \\
\hline $\mathrm{C}_{6}-\mathrm{C}_{0-1}(\%)^{c}$ & 34.1 & 57.4 & 36.1 & 38.7 & 30.6 \\
\hline
\end{tabular}

\footnotetext{
${ }^{a}$ Mean molar abundances of main Py-GC/MS marker compounds (attaining $1 \%$ in at least one sample). ${ }^{b}$ Percentage of oxidized compounds bearing a carboxyl/ carbonyl group. ${ }^{c}$ Percentage of compounds bearing a side chain of only $0-1 \mathrm{C}$
} atoms.

modifications in lignin have been investigated in detail (38) including kraft pulping of eucalypt wood (4). Residual lignin from the unbleached kraft pulp and kraft lignin from the pulping liquor were analyzed after E. globulus wood pulping. As already reported, the yield of enzymatic residual lignin from eucalypt pulps was relatively low, attaining $30 \%$ in unbleached kraft pulp and even lower values in bleached pulps (12), but the lignins obtained exhibited high purity and maintained its unaltered chemical structure (13).

A preferential solubilization of S-rich lignin was produced during pulping, as shown by the high (over 5) S/G ratio of kraft lignin estimated by Py-GC/MS (and HSQC NMR). However, the lignin $\mathrm{S} / \mathrm{G}$ ratio in kraft pulp was only slightly modified with respect to MWL, suggesting the release of simple (nonprecipitable) $\mathrm{G}$ type compounds during pulping. Topological reasons, related to lignin distribution in wood tissues and cell wall layers, could affect lignin attack in addition to the different reactivities of its aromatic units.

Lignin interunit linkages were affected by kraft pulping. In the kraft pulp lignin, a certain decrease of side chain HSQC cross-signals was observed, but their relative abundance was not strongly modified $\left(77 \% \beta-O-4^{\prime}, 18 \%\right.$ resinol, and $1 \%$ phenylcoumaran side chains). This contrasted with the enrichment in $\beta-O-4^{\prime}$ substructures reported for eucalypt pulp residual lignin (4). Signals with $\delta_{\mathrm{C}} / \delta_{\mathrm{H}} 51 / 3.1 \mathrm{ppm}$ could correspond to unidentified $\beta-\beta^{\prime}$ substructures found in eucalypt wood and pulp lignin $(1,39)$. On the other hand, the decrease of side-chain linkages was very significant in kraft lignin, and 
the corresponding cross-signals showed very low intensities. Moreover, the relative abundance of the surviving interunit bonds was dramatically modified, resulting in a high percentage of resinol linkages (77\% side chains) whereas the $\beta-O-4^{\prime}$ percentage was comparatively low (only 15\%). The ratio between resinol and $\beta-O-4^{\prime}$ substructures in this lignin was higher than reported for other kraft lignins $(25,26)$, a fact that could be related to differences in the kraft lignin isolation method in addition to differences in cooking and raw material characteristics. Py-GC/MS confirmed the extensive removal of side chains in kraft lignin, as shown by the high percentage (57\%) of lignin breakdown products with shortened chains, as compared with MWL (34\%). Sinapyl and coniferyl alcohols and aldehydes, which were among the main Py-GC/MS breakdown products from MWL, in accordance with the literature (40), were absent from the kraft lignin pyrograms.

HSQC cross-signals of new terminal structures appeared after kraft pulping. $\mathrm{C}_{\beta}$-oxidized terminal structures $(\mathrm{Ar}-\mathrm{CHOH}-$ $\mathrm{COOH}$ ) were tentatively assigned in the HSQC spectra of both lignins, representing $2 \%$ of side chains in kraft pulp residual lignin and up to $8 \%$ in kraft lignin due to destruction of other side chains. Similar aromatic hydroxyacids had been reported in pine kraft lignin as intermediates in side-chain degradation (26), and a signal with the same $\delta_{\mathrm{C}} / \delta_{\mathrm{H}}$ was found in preliminary characterization of eucalypt kraft lignin (29). Moreover, some increase of sinapyl alcohol substructures was observed in kraft pulp lignin (2\%), in agreement with the formation of these structures during pulping (26). In addition to the above $\mathrm{C}_{\beta}$-oxidized structures, frequent $\mathrm{C}_{\alpha}$ oxidation in kraft lignin was suggested by the $\mathrm{C}_{2,6}-\mathrm{H}_{2,6}$ correlation signals in $\mathrm{S}$ units discussed in the next section.

The extensive breakdown of $\beta-O-4^{\prime}$ linkages during pulping, together with eventual demethoxylation or hydroxylation, resulted in a very high phenolic content of kraft lignin (4), as compared with MWL where etherified units were predominant. This agreed with the high intensity of the $1770 \mathrm{~cm}^{-1}$ band of aromatic acetates in the FTIR spectrum of acetylated samples (18). In pulp lignin, over $35 \%$ units were phenolic, a percentage lower than reported for acidolysis lignin from eucalypt pulp with a similar degree of delignification (4). The relative percentage of aliphatic hydroxyls strongly decreased in the kraft lignin, as compared with MWL, in agreement with side-chain removal and eventual demethoxylation.

As shown by the whole spectra, an increased amount of aliphatic structures was produced in pulp lignin, the aliphatic nonoxygenated region (DMSO signal excluded) representing $16 \%$ of the total HSQC signals in kraft pulp lignin and only $8 \%$ in MWL and kraft lignin. The HMBC spectrum showed the presence of fatty acids that were not detected in MWL, in agreement with reports suggesting lipid incorporation into kraft pulp lignin (4). Whereas the kraft lignin (and MWL) HSQC spectra were basically depleted of carbohydrate correlations, intense cross-signals assigned to xylan (25) were found in the kraft pulp lignin. In fact, this preparation seems to be a lignincarbohydrate complex, containing glucose and xylose and lower amounts of arabinose and galactose units (unpublished results). Xylan and unassigned glucan cross-signals were present, together with those of $\beta-O-4^{\prime}$ substructures $\mathrm{C}_{\alpha} / \mathrm{C}_{\gamma}$-etherified to carbohydrate (most probably hexopyranose units linked to the main xylan) (41). A small percentage of direct xylan-lignin linkages was suggested by a very minor cross-signal with $\delta_{\mathrm{C}}$ $\delta_{\mathrm{H}} 102.2 / 4.92 \mathrm{ppm}$, assigned to xylose $\mathrm{C}_{1}$ forming a glycosidic type linkage with a phenolic hydroxyl (42). Carbohydrate crosssignals have been found in spectra of other residual lignins, being assigned to pentose and hexose units $(3,25,28)$. A contaminant identified as poly(ethyleneoxy-propyleneoxy) was found in all of the pulp residual lignins but was absent from MWL and kraft lignin, suggesting that it originated from material used in solvent purification of lignins. The same contaminant has been reported in spruce pulp residual lignin (25).

Effect of Oxygen on Eucalypt Pulp Lignin. Oxygen delignification was introduced in the 1970s for manufacturing both elementary chlorine free (ECF) and TCF pulps. There is abundant literature on the effect of oxygen on the lignin in pulps from different woods (43) including eucalypt wood (3).

HSQC NMR suggested a decrease of lignin S/G ratio by oxygen, but this was not confirmed by Py-GC/MS. The intensity of side-chain signals and the relative abundance of interunit linkages were similar to those found in the unbleached kraft pulp lignin (78\% $\beta-O-4^{\prime}, 15 \%$ resinol, and $1 \%$ phenylcoumaran). Terminal sinapyl alcohol (4\%) and putative $\mathrm{Ar}-$ $\mathrm{CHOH}-\mathrm{COOH}(2 \%)$ structures were also observed. In this sense, it has been reported that oxygen mainly acts on superficial pulp lignin, total lignin maintaining most of its structural features (44).

Oxygen delignification resulted in an increase of oxidized $\mathrm{S}$ units (estimated from the aromatic $\mathrm{C}_{2,6}-\mathrm{H}_{2,6}$ cross-signal). This agreed with the increased amount of oxidized lignin markers after Py-GC/MS. Oxidized $\mathrm{G}$ units have been detected in pine pulp residual lignin from similar $\mathrm{C}_{2}-\mathrm{H}_{2}$ and $\mathrm{C}_{6}-\mathrm{H}_{6}$ correlation signals $(26,30)$. HMBC correlations between the aromatic $\mathrm{H}_{2,6}$ and side-chain carbons demonstrated that the oxidized $\mathrm{S}$ units presented a $\mathrm{C}_{\alpha}$ carbonyl group $\left(\delta_{\mathrm{C}} 197.9 \mathrm{ppm}\right)$, whereas the normal $\mathrm{S}$ units had a hydroxylated $\mathrm{C}_{\alpha}$ in a $\beta-O-4^{\prime}$ substructure $\left(\delta_{\mathrm{C}} 72.3 \mathrm{ppm}\right)$. Moreover, its characteristic $\delta_{\mathrm{C}}$ indicated that the conjugated carbonyl in lignin from the oxygen-delignified eucalypt pulp was a ketone group. $\mathrm{C}_{\alpha}$ ketones in $\beta-O-4^{\prime}$ substructures $(2,39)$ were found in the eucalypt MWL, but the absence of a cross-signal with $\delta_{\mathrm{C}} / \delta_{\mathrm{H}} 83 / 4.5 \mathrm{ppm}$ showed that similar structures in oxygen-delignified pulp residual lignin did not present a $\mathrm{C}_{\beta}$ ether linkage, most probably because of alkaline breakdown (25). Moreover, the HMBC correlation between $\mathrm{H}_{2,6}$ and $\mathrm{C}_{3,5}$ in $\mathrm{S}$ units showed that most normal units were $\mathrm{C}_{4}$ etherified $\left(\delta_{\mathrm{C}} / \delta_{\mathrm{H}} 152 / 6.7 \mathrm{ppm}\right)$ whereas the $\mathrm{C}_{\alpha}=\mathrm{O}$ units were predominantly phenolic $\left(\delta_{\mathrm{C}} / \delta_{\mathrm{H}} 148 / 7.3 \mathrm{ppm}\right)$. Therefore, syringone type structures $(\mathrm{HO}-\mathrm{S}-\mathrm{CO}-\mathrm{R})$ were identified in the E. globulus pulp lignin after oxygen delignification.

It is generally accepted that the action of oxygen on lignin focuses on the phenolic units, resulting in ring opening and muconic acid formation, although the latter compounds are often present in minor amounts due to their high reactivity (45). However, the residual lignin from oxygen-delignified eucalypt pulp still contained near $30 \%$ phenolic units (a percentage lower than found in unbleached kraft pulp), and muconic acid formation could not be demonstrated. This indicated that lack of phenolic structures is not the limiting factor in oxygen bleaching of eucalypt kraft pulp, as found also for other pulp types (46).

It has been reported that oxygen delignification of softwood pulp resulted in residual lignin enriched in $\mathrm{H}$ units (46). When lignin was analyzed directly in the pulp (47), the increase could be due to higher recalcitrance of $\mathrm{H}$ units (46) but it has also been related to polysaccharide oxidation products $(48)$. When enzymatically isolated lignins were analyzed (46), the supposed enrichment is probably due to protein contamination, since tyrosine residues and lignin $\mathrm{H}$ units are difficult to distinguish 
by $2 \mathrm{D}$ NMR (same $\mathrm{C}_{3,5}-\mathrm{H}_{3,5}$ and $\mathrm{C}_{2,6}-\mathrm{H}_{2,6}$ correlations) and yield similar Py-GC/MS products.

An increase of aliphatic cross-signals was observed in the whole HSQC spectrum of residual lignin after oxygen treatment, the aliphatic nonoxygenated region representing more than $25 \%$ of the total HSQC signals, as compared with $16 \%$ in unbleached kraft pulp lignin. This could be due to alkyl structures in degraded lignin and fatty acids (49), whose presence was confirmed by HMBC. The relative intensity of xylan crosssignals in the HSQC spectra increased after oxygen delignification, as compared with the unbleached kraft pulp lignin.

Effect of Alkaline Hydrogen Peroxide on Eucalypt Pulp Lignin. Hydrogen peroxide is a common bleaching agent in industrial TCF processes, often in combination with oxygen delignification. The chemistry of peroxide bleaching has been described, including its effect on pulp lignin (43).

In contrast to that observed in oxygen delignification, peroxide bleaching caused a slight increase of the lignin S/G ratio and modified the relative abundances of interunit linkages and terminal structures. In particular, the resinol amount was lowered to only $6 \%$ side chains (against $15 \%$ in residual lignin from oxygen-delignified pulp) and that of $\beta-O-4^{\prime}$ substructures increased to a value similar to that found in MWL $(81 \%$ of side chains) whereas $3 \%$ phenylcoumaran side chains were found. The erythro/threo ratio of $\beta-O-4^{\prime}$ side chains decreased from 8.3 in MWL to 6.9 in the bleached pulp, in accordance with the tendency reported in the literature (25). In the HSQC spectrum of the final pulp residual lignin, $\beta-O-4^{\prime}$ substructures with a $\mathrm{C}_{\alpha} \cdot \mathrm{OOH}$ second unit (4\% side chains) were tentatively identified $(25,29)$. Other structures identified in unbleached and oxygen-delignified pulp lignins were still present in the final pulp lignin (1\% sinapyl alcohol and $4 \% \mathrm{Ar}-\mathrm{CHOH}-\mathrm{COOH})$. A very small cross-signal with $\delta_{\mathrm{C}} / \delta_{\mathrm{H}} 80.2 / 5.49 \mathrm{ppm}$ in the HSQC spectrum of the residual lignin from the final pulp would correspond to $\mathrm{C}_{\alpha}-\mathrm{H}_{\alpha}$ correlation in $\alpha-O-4^{\prime} / \beta-O-4^{\prime}$ substructures (27). Noncyclic $\alpha-O-4^{\prime}$ structures were reported to be below the NMR detection limits in MWL from E. globulus (2), but they were found in low amount $(0.23 \%$ units) in $E$. globulus wood dioxane lignin (1). An unidentified aromatic signal with $\delta_{\mathrm{C}} / \delta_{\mathrm{H}} 108.9 / 6.71 \mathrm{ppm}$ was found in the lignin isolated after the peroxide treatment of pulp. Removal of aromatic ring-conjugated ketones by alkaline peroxide will contribute to pulp bleaching, since they act as chromophoric groups. In contrast, the abundance of terminal structures with conjugated and nonconjugated carboxyls increased. The former was identified by the characteristic $\delta_{\mathrm{C}} 167.3 \mathrm{ppm}$ HMBC correlation.

The residual lignin from peroxide-bleached pulp included some contaminating protein. This resulted in four main crosssignals in the HSQC aromatic region (one of them overlapping with $\mathrm{C}_{5}-\mathrm{H}_{5}$ cross-signal in $\mathrm{G}$ units) and several small signals, as reported for enzymatic lignin from peroxide-bleached pine pulp (28). This contamination was confirmed by protein markers (indole and 3-methylindole) after Py-GC/MS (12). It most probably originated from the cellulase used in lignin isolation, a fact supported by the HMQC spectrum of this enzyme (30). Taking into account the tryptophan plus tyrosine content of cellulase (50), a maximal protein content of $15 \%$ could be estimated by Py-GC/MS, in agreement with an $1-2 \% \mathrm{~N}$ content. However, this protein did not hamper 2D NMR analysis of residual lignins since no overlapping with the most informative cross-signals was produced (30) and it could be detected by Py-GC/MS (13).

The aliphatic nonoxygenated region showed nearly the same intensity ( $23 \%$ of total HSQC signals) than in the residual lignin from oxygen-delignified pulp (25\%). However, the relative intensities of the xylan cross-signals decreased, and those assigned to lignin-carbohydrate benzyl-ether linkages were nearly absent from the residual lignin of the final pulp. Partial breakdown of the above linkages has been reported during treatment of pine kraft pulp with hydrogen peroxide in the presence of manganese complexes (28).

The E. globulus wood lignin, as revealed by MWL analysis, is a basically linear polymer mainly constituted by $\beta-O-4^{\prime}$ and syringaresinol substructures. Pulping caused partial degradation of lignin unit side chains resulting in depolymerization and solubilization of strongly phenolic kraft lignin with a high predominance of resinol type side chain linkages. The alteration degree of residual lignin in pulp increased during oxygen delignification. The presence of $\mathrm{C}_{\alpha}$ ketones in phenolic units surviving oxygen treatment was shown by HSQC and HMBC NMR. These and other chromophoric groups were partially removed in the hydrogen peroxide stage $(\mathrm{P})$, whereas conjugated and nonconjugated carboxyls were still present in the final pulp residual lignin. In this way, a brightness near $88 \%$ ISO, with a $\kappa$ number of 3.4 (after hexenuronic acid deduction), was attained in the TCF-bleached pulp.

\section{ABBREVIATIONS USED}

DMSO, dimethylsulfoxide; ECF, elementary chlorine free; FTIR, Fourier transform infrared; G, guaiacyl; HMBC, heteronuclear multiple bond correlation; HSQC, heteronuclear single quantum correlation; MWL, milled wood lignin; NMR, nuclear magnetic resonance; $\mathrm{O}$, oxygen stage; $\mathrm{P}$, hydrogen peroxide stage; Po, hydrogen peroxide stage under pressurized oxygen; Py-GC/MS, pyrolysis-gas chromatography/mass spectrometry; $\mathrm{Q}$, chelation stage; S, syringyl; TCF, totally chlorine free; TOCSY, total correlation spectroscopy.

Supporting Information Available: FTIR spectra, 600-2000 $\mathrm{cm}^{-1}$, of eucalypt MWL, kraft lignin, and residual lignins from unbleached, oxygen-delignified, and TCF-bleached eucalypt kraft pulps. This material is available free of charge via the Internet at http://pubs.acs.org.

\section{LITERATURE CITED}

(1) Evtuguin, D. V.; Neto, C. P.; Silva, A. M. S.; Domingues, P. M.; Amado, F. M. L.; Robert, D.; Faix, O. Comprehensive study on the chemical structure of dioxane lignin from plantation Eucalyptus globulus wood. J. Agric. Food Chem. 2001, 49, 4252-4261.

(2) Capanema, E. A.; Balakshin, M. Y.; Kadla, J. F. Quantitative characterization of a hardwood milled wood lignin by nuclear magnetic resonance spectroscopy. J. Agric. Food Chem. 2005, $53,9639-9649$.

(3) Duarte, A. P.; Robert, D.; Lachenal, D. Eucalyptus globulus kraft pulp residual lignin. Part 2. Modification of residual lignin structure in oxygen bleaching. Holzforschung 2001, 55, 645651.

(4) Pinto, P. C.; Evtuguin, D. V.; Neto, C. P.; Silvestre, A. J. D.; Amado, F. M. L. Behavior of Eucalyptus globulus lignin during kraft pulping. II. Analysis by NMR, ESI/MS, and GPC. J. Wood Chem. Technol. 2002, 22, 109-125.

(5) Björkman, A. Studies on finely divided wood. Part I. Extraction of lignin with neutral solvents. Sven. Papperstidn. 1956, 13, 477-485.

(6) Holtman, K. M.; Chang, H. M.; Jameel, H.; Kadla, J. F. Quantitative C-13 NMR characterization of milled wood lignins isolated by different milling techniques. J. Wood Chem. Technol. 2006, 26, 21-34. 
(7) Gellerstedt, G.; Pranda, J. Structural and molecular properties of residual birch lignins. J. Wood Chem. Technol. 1994, 14, 467482.

(8) Adler, E. Lignin chemistry-Past, present and future. Wood Sci. Technol. 1977, 11, 169-218.

(9) Hortling, B.; Ranua, M.; Sundquist, J. Investigation of the residual lignin in chemical pulps. Part 1. Enzymatic hydrolysis of the pulps and fractionation of the products. Nord. Pulp Pap. Res. J. 1990, 5, 33-37.

(10) Argyropoulos, D. S.; Sun, Y.; Paluš, E. Isolation of residual kraft lignin in high yield and purity. J. Pulp Pap. Sci. 2002, 28, 5054.

(11) Capanema, E. A.; Balakshin, M. Y.; Chen, C. L. An improved procedure for isolation of residual lignins from hardwood kraft pulps. Holzforschung 2004, 58, 464-472.

(12) Ibarra, D.; del Río, J. C.; Gutiérrez, A.; Rodríguez, I. M.; Romero, J.; Martínez, M. J.; Martínez, A. T. Isolation of high-purity residual lignins from eucalypt paper pulps by cellulase and proteinase treatments followed by solvent extraction. Enzyme Microb. Technol. 2004, 35, 173-181.

(13) Ibarra, D.; del Río, J. C.; Gutiérrez, A.; Rodríguez, I. M.; Romero, J.; Martínez, M. J.; Martínez, A. T. Chemical characterization of residual lignins from eucalypt paper pulps. J. Anal. Appl. Pyrolysis 2005, 74, 116-122.

(14) Lin, S. Y.; Dence, C. W. Methods in Lignin Chemistry; SpringerVerlag: Berlin, 1992.

(15) Higuchi, T. Biochemistry and Molecular Biology of Wood; Springer-Verlag: London, 1997.

(16) del Río, J. C.; Gutiérrez, A.; Hernando, M.; Landín, P.; Romero, J.; Martínez, A. T. Determining the influence of eucalypt lignin composition in paper pulp yield using Py-GC/MS. J. Anal. Appl. Pyrolysis 2005, 74, 110-115.

(17) del Río, J. C.; Gutiérrez, A.; Romero, J.; Martínez, M. J.; Martínez, A. T. Identification of residual lignin markers in eucalypt kraft pulps by Py-GC/MS. J. Anal. Appl. Pyrolysis 2001, $58 / 59,425-433$.

(18) Faix, O. Fourier transform infrared spectroscopy. In Methods in Lignin Chemistry; Lin, S. Y., Dence, C. W., Eds.; SpringerVerlag: Berlin, 1992; pp 83-109.

(19) Nimz, H. H.; Robert, D.; Faix, O.; Nemr, M. Carbon-13 NMR spectra of lignins 8. Structural differences between lignins of hardwoods; softwoods; grasses and compression wood. Holzforschung 1981, 35, 16-26.

(20) Ralph, J.; Marita, J. M.; Ralph, S. A.; Hatfield, R. D.; Lu, F.; Ede, R. M.; Peng, J.; Quideau, S.; Helm, R. F.; Grabber, J. H.; Kim, H.; Jimenez-Monteon, G.; Zhang, Y.; Jung, H.-J. G.; Landucci, L. L.; MacKay, J. J.; Sederoff, R. R.; Chapple, C.; Boudet, A. M. Solution-state NMR of lignin. In Advances in Lignocellulosics Characterization; Argyropoulos, D. S., Ed.; Tappi Press: Atlanta, 1999; pp 55-108.

(21) Fukagawa, N.; Meshitsuka, G.; Ishizu, A. A 2-dimensional NMRstudy of birch milled wood lignin. J. Wood Chem. Technol. 1991, 11, 373-396.

(22) Ede, R. M.; Brunow, G. Application of two-dimensional homonuclear and heteronuclear correlation NMR spectroscopy to wood lignin structure determination. J. Org. Chem. 1992, 57, 14771480.

(23) Karhunen, P.; Rummakko, P.; Sipila, J.; Brunow, G.; Kilpeläinen, I. Dibenzodioxocins-A novel type of linkage in softwood lignins. Tetrahedron Lett. 1995, 36, 169-170.

(24) Zhang, L.; Gellerstedt, G. NMR observation of a new lignin structure, a spiro-dienone. Chem. Commun. 2001, 2744-2745.

(25) Liitiä, T. M.; Maunu, S. L.; Hortling, B.; Toikka, M.; Kilpeläinen, I. Analysis of technical lignins by two- and three-dimensional NMR spectroscopy. J. Agric. Food Chem. 2003, 51, 2136-2143.

(26) Balakshin, M. Y.; Capanema, E. A.; Chen, C.-L.; Gracz, H. S. Elucidation of the structures of residual and dissolved pine kraft lignins using an HMQC NMR technique. J. Agric. Food Chem. 2003, 51, 6116-6127.
(27) Ämmälahti, E.; Brunow, G.; Bardet, M.; Robert, D.; Kilpeläinen, I. Identification of side-chain structures in a poplar lignin using three-dimensional HMQC-HOHAHA NMR spectroscopy. $J$. Agric. Food Chem. 1998, 46, 5113-5117.

(28) Chen, C.-L.; Capanema, E. A.; Gracz, H. S. Comparative studies on the delignification of pine kraft- anthraquinone pulp with hydrogen peroxide by binucleus Mn(IV) complex catalysis. $J$. Agric. Food Chem. 2003, 51, 6223-6232.

(29) Capanema, E. A.; Balakshin, M. Y.; Chen, C.-L.; Gratzl, J. S.; Gracz, H. Structural analysis of residual and technical lignins by ${ }^{1} \mathrm{H}-{ }^{13} \mathrm{C}$ correlation 2D NMR-spectroscopy. Holzforschung 2001, 55, 302-308.

(30) Balakshin, M.; Capanema, E.; Chen, C.-L.; Gratzl, J.; Kirkman, A.; Gracz, H. Biobleaching of pulp with dioxygen in the laccasemediator system-Reaction mechanisms for degradation of residual lignin. J. Mol. Catal. B: Enzym. 2001, 13, 1-16.

(31) Heikkinen, S.; Toikka, M. M.; Karhunen, P. T.; Kilpeläinen, I. A. Quantitative 2D HSQC (Q-HSQC) via suppression of J-dependence of polarization transfer in NMR spectroscopy: Application to wood lignin. J. Am. Chem. Soc. 2003, 125, 43624367.

(32) Zhang, L. M.; Gellerstedt, G. Quantitative 2D HSQC NMR determination of polymer structures by selecting suitable internal standard references. Magn. Reson. Chem. 2007, 45, 37-45.

(33) International Organisation for Standardization Documentation and Information (ISO). ISO Standards Collection on CD-ROM. Paper, Board and Pulps, 2nd ed.; ISO: Geneva, 2003.

(34) Ralph, S. A.; Ralph, J.; Landucci, L. NMR Database of Lignin and Cell Wall Model Compounds; U.S. Forest Prod. Lab.: Madison, WI, 2004; http://ars.usda.gov/Services/ docs.htm?docid=10491H (accessed: July 2006).

(35) Capanema, E. A.; Balakshin, M. Y.; Kadla, J. F. A comprehensive approach for quantitative lignin characterization by NMR spectroscopy. J. Agric. Food Chem. 2004, 52, 1850-1860.

(36) Faix, O.; Grunwald, C.; Beinhoff, O. Determination of phenolic hydroxyl group content of milled wood lignins (MWL's) from different botanical origins using selective aminolysis, FTIR, ${ }^{1} \mathrm{H}-$ NMR, and UV spectroscopy. Holzforschung 1992, 46, 425432.

(37) Brunow, G.; Karlsson, O.; Lundquist, K.; Sipilä, J. On the distribution of diastereomers of the structural elements in lignin: The steric course of reactions mimicking lignin biosynthesis. Wood Sci. Technol. 1993, 27, 281-286.

(38) Gellerstedt, G.; Lindfors, E. L. Structural changes in lignin during kraft cooking. Holzforschung 1984, 39, 151-158.

(39) Gaspar, A.; Evtuguin, D. V.; Neto, C. P. Lignin reactions in oxygen delignification catalysed by $\mathrm{Mn}(\mathrm{II})$-substituted molybdovanadophosphate polyanion. Holzforschung 2004, 58, 640649.

(40) Al Dajani, W. W.; Gellerstedt, G. On the isolation and structure of softwood residual lignins. Nord. Pulp Pap. Res. J. 2002, 17, 193-198.

(41) Shatalov, A. A.; Evtuguin, D. V.; Pascoal Neto, C. (2-O- $\alpha-D-$ galactopyranosyl-4-O-methyl- $\alpha$-D-glucurono)-D-xylan from Eucalyptus globulus Labill. Carbohydr. Res. 1999, 320, 9399.

(42) Balakshin, M. Y.; Evtuguin, D. V.; Neto, C. P.; Silva, A. M. S.; Domingues, P.; Amado, F. M. L. Studies on lignin and lignincarbohydrate complex by application of advanced spectrocopic techniques. Proc. 11th ISWPC, Nice, 11-14 June 2001; pp 103106.

(43) Argyropoulos, D. S. Oxidative Delignification Chemistry: Fundamentals and Catalysis; American Chemical Society: Washington, DC, 2001.

(44) Gellerstedt, G.; Heuts, L.; Robert, D. Structural changes in lignin during a totally chlorine free bleaching sequence. Part II: An NMR study. J. Pulp Pap. Sci. 1999, 25, 111-117.

(45) Evtuguin, D. V.; Robert, D. The detection of muconic acid type structures in oxidized lignins by C-13 NMR spectroscopy. Wood Sci. Technol. 1997, 31, 423-431. 
(46) Akim, L. G.; Colodette, J. L.; Argyropoulos, D. S. Factors limiting oxygen delignification of kraft pulp. Can. J. Chem. 2001, 79, 201-210.

(47) Ohra-aho, T.; Tenkanen, M.; Tamminen, T. Direct analysis of lignin and lignin-like components from softwood kraft pulp by Py-GC/MS techniques. J. Anal. Appl. Pyrolysis 2005, 74, 123128.

(48) Tamminen, T.; Kleen, M.; Ohra-aho, T.; Poppius-Levlin, K. Chemistry of mediated-laccase delignification analyzed by pyrolysis-GC/MS. J. Pulp Pap. Sci. 2003, 29, 319-324.

(49) Marlin, N.; Lachenal, D.; Magnin, L.; Brochier-Salon, M. C. Study of the oxygen effect on mechanical pulp lignin using an improved lignin isolation method. Holzforschung 2005, 59, 116123.
(50) Shoemaker, S.; Schweickart, V.; Ladner, M.; Gelfand, D.; Kwok, S.; Myambo, K.; Innis, M. Molecular-cloning of exo-cellobiohydrolase-I derived from Trichoderma reesei strain-L27. BioTechnology 1983, 1, 691-696.

Received for review December 22, 2006. Revised manuscript received February 21, 2007. Accepted February 22, 2007. The study was funded by the Spanish projects BIO2005-03569, AGL2005-01748 and CTQ200508925-C02-02, the EU contracts QLK3-99-590 and FP6-2004-NMP-NI4-02456, the CSIC project 2006-4-0I-039, and two ENCE-CSIC contracts.

JF063728T 